\title{
Geologic Map of the Fraser 7.5-minute Quadrangle, Grand County, Colorado
}

zon 4 \%

6.

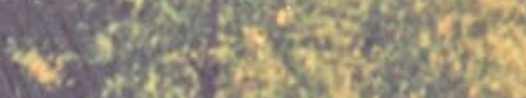

\section{$\frac{214}{4010}$}

\section{Pamphlet to accompany} and

\section{Soientific Investigations Map 3130}
ite
0.030 .8300
26
Us ineprtment of

4.

20.

(2)

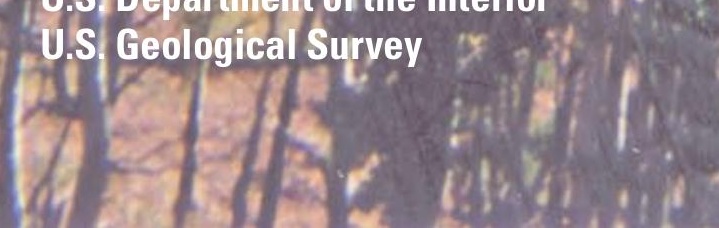

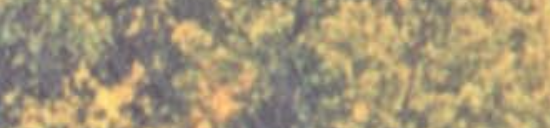

S.6.3.
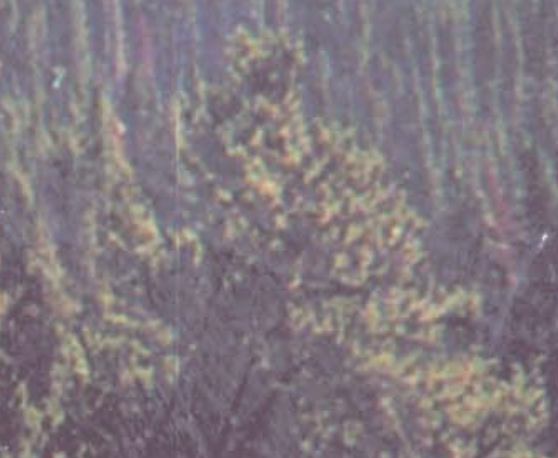


\section{COVER:}

View to the southeast, from high gravel-capped hill near the town of Winter Park, looking toward snowclad peaks along the Continental Divide east of Berthoud Pass. High peak on the far left is James Peak, $13,294 \mathrm{ft},(4,052 \mathrm{~m})$. In foreground, the dense forest is composed of conifers and aspen, and is growing in soils formed in surficial deposits and weathered bedrock. Photograph by R.R. Shroba, September 26, 2006. 


\section{Geologic Map of the Fraser 7.5-minute Quadrangle, Grand County, Colorado}

By Ralph R. Shroba, Bruce Bryant, Karl S. Kellogg, Paul K. Theobald, and Theodore R. Brandt

Pamphlet to accompany

Scientific Investigations Map 3130 


\title{
U.S. Department of the Interior \\ KEN SALAZAR, Secretary \\ U.S. Geological Survey \\ Marcia K. McNutt, Director
}

\author{
U.S. Geological Survey, Reston, Virginia: 2010
}

For more information on the USGS--the Federal source for science about the Earth, its natural and living resources, natural hazards, and the environment: visit http://www.usgs.gov or call 1-888-ASK-USGS

For an overview of USGS information products, including maps, imagery, and publications, visit http://www.usgs.gov/pubprod

To order this and other USGS information products, visit http://www.store.usgs.gov

Any use of trade, product, or firm names is for descriptive purposes only and does not imply endorsement by the U.S. Government.

Although this report is in the public domain, permission must be secured from the individual copyright owners to reproduce any copyrighted materials contained within this report.

Suggested citation:

Shroba, R.R., Bryant, Bruce, Kellogg, K.S., Theobald, P.K., and Brandt, T.R., 2010, Geologic map of the Fraser 7.5-minute quadrangle, Grand County, Colorado: U.S. Geological Survey Scientific Investigations Map 3130, scale 1:24,000, 1 sheet, 26 p. pamphlet. [Available at URL http://pubs.usgs.gov/sim/3130]. 


\section{Contents}

Introduction.

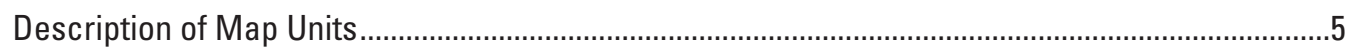

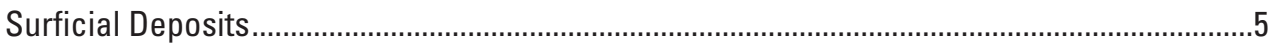

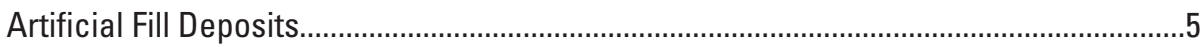

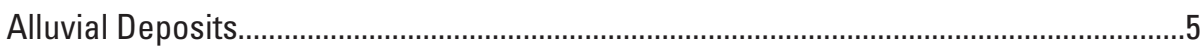

Alluvial and Mass-Movement Deposits ........................................................................

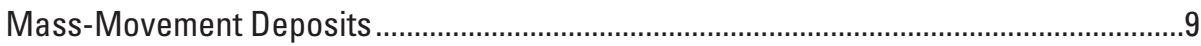

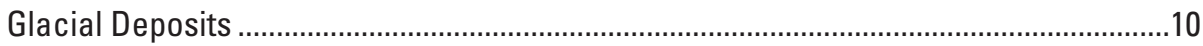

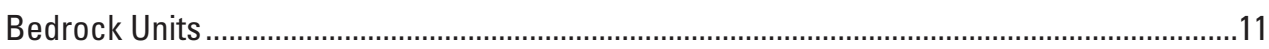

Post-Laramide Sedimentary and Volcanic Rocks ..........................................................11

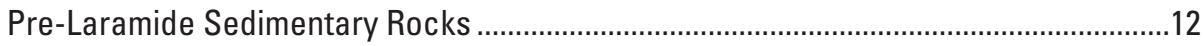

Proterozoic Rocks...........................................................................................................12

Eolian Silt Contributions to the Troublesome Formation in the Fraser Basin....................................14

Structural Setting of the Fraser 7.5-minute Quadrangle ...............................................................16

Geologic History of the Fraser 7.5-minute Quadrangle ............................................................16

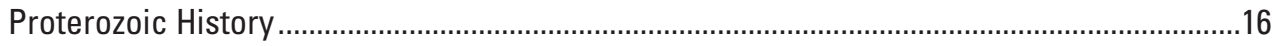

Paleozoic through Laramide History ...................................................................................... 17

Post-Laramide Cenozoic History .....................................................................................17

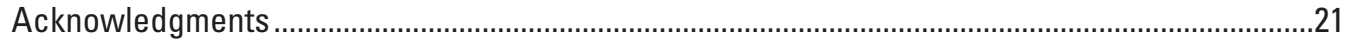

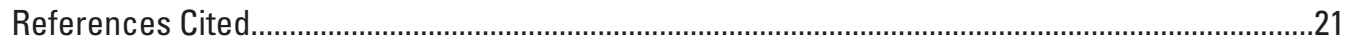

\section{Figures}

1. Index of 7.5- and 15-minute quadrangles referred to in this report .............................

2. Regional geologic setting of parts of the Front and Gore Ranges

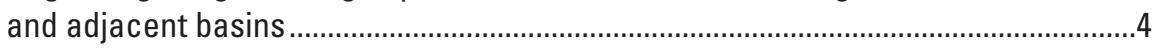

3. Index of geologic mapping in figure 2 ......................................................................

4. Plot of mean particle size and degree of sorting (standard deviation of the mean particle size) of silty sandstone, siltstone, and clayey siltstone collected from the Troublesome Formation near Fraser, Colorado.....

\section{Tables}

1. Particle-size analyses of silty sandstone, siltstone, and clayey siltstone collected from the Troublesome Formation near Fraser, Colorado

2. Approximate height, in meters, of top of gravelly stream alluvium $(\mathrm{Og}$ and $\mathrm{QNg})$ above the Fraser River and its major tributaries:

Saint Louis Creek and Ranch Creek in the Fraser 7.5-minute quadrangle..

3. Mean annual precipitation near Kremmling, Granby, and Fraser, Colorado

4. Mean January and July temperatures near Fraser, Colorado, and estimated mean January and July temperatures near the Mary Jane site, about 9 km southeast of Fraser 


\section{Conversion Factors}

\begin{tabular}{llc}
\hline Multiply & By & To obtain \\
\hline centimeter $(\mathrm{cm})$ & Length & \\
meter $(\mathrm{m})$ & 0.3937 & inch (in.) \\
kilometer $(\mathrm{km})$ & 3.281 & foot (ft) \\
square kilometers $\left(\mathrm{km}^{2}\right)$ & 0.6214 & mile (mi) \\
\hline
\end{tabular}

Temperature in degrees Celsius $\left({ }^{\circ} \mathrm{C}\right)$ may be converted to degrees Fahrenheit $\left({ }^{\circ} \mathrm{F}\right)$ as follows:

${ }^{\circ} \mathrm{F}=\left(1.8 \times{ }^{\circ} \mathrm{C}\right)+32$

Temperature in degrees Fahrenheit $\left({ }^{\circ} \mathrm{F}\right)$ may be converted to degrees Celsius $\left({ }^{\circ} \mathrm{C}\right)$ as follows:

${ }^{\circ} \mathrm{C}=\left({ }^{\circ} \mathrm{F}-32\right) / 1.8$

Altitude, as used in this report, refers to distance above the vertical datum. 


\section{Divisions of Quaternary, Neogene, and Paleogene time used in this report}

\begin{tabular}{|c|c|c|c|}
\hline Period or Subperiod & Epoch & & Age \\
\hline & Holocene & & $0-11.5 \mathrm{ka}$ \\
\hline \multicolumn{4}{|l|}{ Quaternary } \\
\hline & & late & $11.5-132 \mathrm{ka}$ \\
\hline & Pleistocene & middle & $132-788 \mathrm{ka}$ \\
\hline & & early & $788 \mathrm{ka}-1.81 \mathrm{Ma}$ \\
\hline \multirow[t]{2}{*}{ Neogene } & Pliocene & & $1.81-5.33 \mathrm{Ma}$ \\
\hline & Miocene & & $5.33-23.0 \mathrm{Ma}$ \\
\hline \multirow[t]{3}{*}{ Paleogene } & Oligocene & & $23.0-33.9 \mathrm{Ma}$ \\
\hline & Eocene & & $33.9-55.8 \mathrm{Ma}$ \\
\hline & Paleocene & & $55.8-65.5 \mathrm{Ma}$ \\
\hline
\end{tabular}

Ages of time boundaries are those of the U.S. Geological Survey Geologic Names Committee (2007) except those for the late-middle Pleistocene and middle-early Pleistocene boundaries, which are those of Richmond and Fullerton (1986a). Ages are expressed in ka for kilo-annum (thousand years) and Ma for mega-annum (million years).

\section{North American land mammal ages used in this report}

\begin{tabular}{ll}
\hline Land Mammal Age & Age \\
\hline Hemphillian & $4.7-8.9 \mathrm{Ma}$ \\
Clarendonian & $8.9-11.6 \mathrm{Ma}$ \\
Arikareean & $19-29 \mathrm{Ma}$ \\
\hline
\end{tabular}

Ages of time boundaries are those of Woodburne and Swisher (1995). 



\title{
Geologic Map of the Fraser 7.5-minute Quadrangle, Grand County, Colorado
}

\author{
By Ralph R. Shroba, Bruce Bryant, Karl S. Kellogg, Paul K. Theobald, and Theodore R. Brandt
}

\section{Introduction}

The geology of the Fraser 7.5-minute quadrangle was compiled from previous and new mapping. Theobald mapped much of the southern one-third of the quadrangle during 1959-1963. Many of the geologic units and geologic features observed by Theobald along old logging roads and some of the aqueduct cuts are no longer visible, due chiefly to the deposition of colluvium and regeneration of dense forest cover. Materials available from Theobald's work in the Fraser quadrangle included a preliminary geologic map of the southern one-third of the quadrangle, field notes, and field sheets. None of his petrographic information, rock samples, or map-unit descriptions was available to the other co-authors.

Bryant made a reconnaissance geologic map of the northern two-thirds of the Fraser quadrangle during 1974 as part of his work on the Denver $1^{\circ} \times 2^{\circ}$ quadrangle geologic map (Bryant and others, 1981). During 2005 and 2006, Bryant spent a few days each field season on the Fraser quadrangle making minor changes to Theobald's mapping and reconnoitered some unmapped areas, chiefly in the northeast part of the quadrangle. Shroba mapped all of the Quaternary and late Neogene surficial deposits and Tertiary bedrock units in the Fraser quadrangle in eight weeks during 2003 and 2005-2008. Kellogg compiled Theobald's unpublished mapping of the Fraser quadrangle and digitized the earlier version of the current geologic map. Brandt prepared the digital compilation of the geologic map, added shaded relief on one of the versions of the geologic map, and prepared the GIS database.

Surficial deposits within the Fraser quadrangle record alluvial, mass-movement, and glacial processes along the western boundary of the Front Range and in the eastern two-thirds of the Fraser basin during the Quaternary and late Neogene. Many of the surficial deposits are poorly exposed. Deposits that are limited in extent were not mapped, including (1) fill material along roads and at building sites, (2) storage piles composed of sand and gravel at an active gravel pit, and (3) thin colluvial deposits that commonly mantle the Troublesome Formation (NPt) and older bedrock units.

The surficial units on this map are informal allostratigraphic units (disconformity-bound sequences) of the North American Stratigraphic Code (North American Commission on Stratigraphic Nomenclature, 1983), whereas the other map units ("bedrock units") are informal or formal lithostratigraphic or informal lithodemic units. For these reasons, subdivisions of allostratigraphic or lithodemic units use time terms "late" and "early" as applied to surficial units or Proterozoic crystalline units, but we use position terms "upper" and "lower" where applied to lithostratigraphic units.

Age assignments for surficial deposits within the map area are based chiefly on relative heights above present stream channels, the relative degree of modification of their original depositional morphology, and degree of soil development and clast weathering.

The mapped distribution of surficial map units is based primarily on interpretation of 1:40,000-scale, color-infrared aerial photographs taken in 1988 (National Aerial Photography Program (NAPP), http://egsc.usgs.gov/isb/pubs/booklets/ aerial/aerial.html) and 1:18,000-scale, natural-color aerial photographs taken in 2000 (U.S. Department of Agriculture, Farm Service Agency, http://www.fsa.usda.gov/FSA/apfoap $p ?$ area $=$ apfohome\&subject $=$ landing\&topic $=$ landing). The approximate boundaries of one active and three inactive gravel pits (indicated by hachured lines) near the northwestern corner of the map area are those observed on year 2000 aerial photographs. Grain or particle sizes of surficial deposits in map-unit descriptions are field estimates. Size limits for sand (2-0.05 $\mathrm{mm})$, silt $(0.05-0.002 \mathrm{~mm})$, and clay $(<0.002 \mathrm{~mm})$ are those of the Soil Survey Staff (1951). Size ranges for the particlessize analyses in table 1 are those of the Wentworth scale (Folk, 1965). In descriptions of surficial map units, the term "clasts" refers to granules and larger particles ( $>2 \mathrm{~mm}$ in diameter), whereas the term "matrix" refers to sand and finer particles ( $\leq 2 \mathrm{~mm}$ in diameter). In descriptions of clast composition of surficial map units, the terms "granite" and "granitic" refer chiefly to granite, pegmatite, and monzogranite. The term "gneiss" refers chiefly to biotite gneiss and hornblende gneiss. In this report, the terms "alluvium" and "alluvial" refer to sediment transported by running water confined to channels (stream alluvium) as well as by running water not confined to channels (sheet flow or unconfined overland flow). The term "colluvium" refers to all rock and sediment transported downslope chiefly by gravity (Hilgard, 1892; Merrill, 1897). Material on slopes is transported chiefly by mass-movement 
Table 1. Particle-size analyses of silty sandstone, siltstone, and clayey siltstone collected from the Troublesome Formation near Fraser, Colorado.

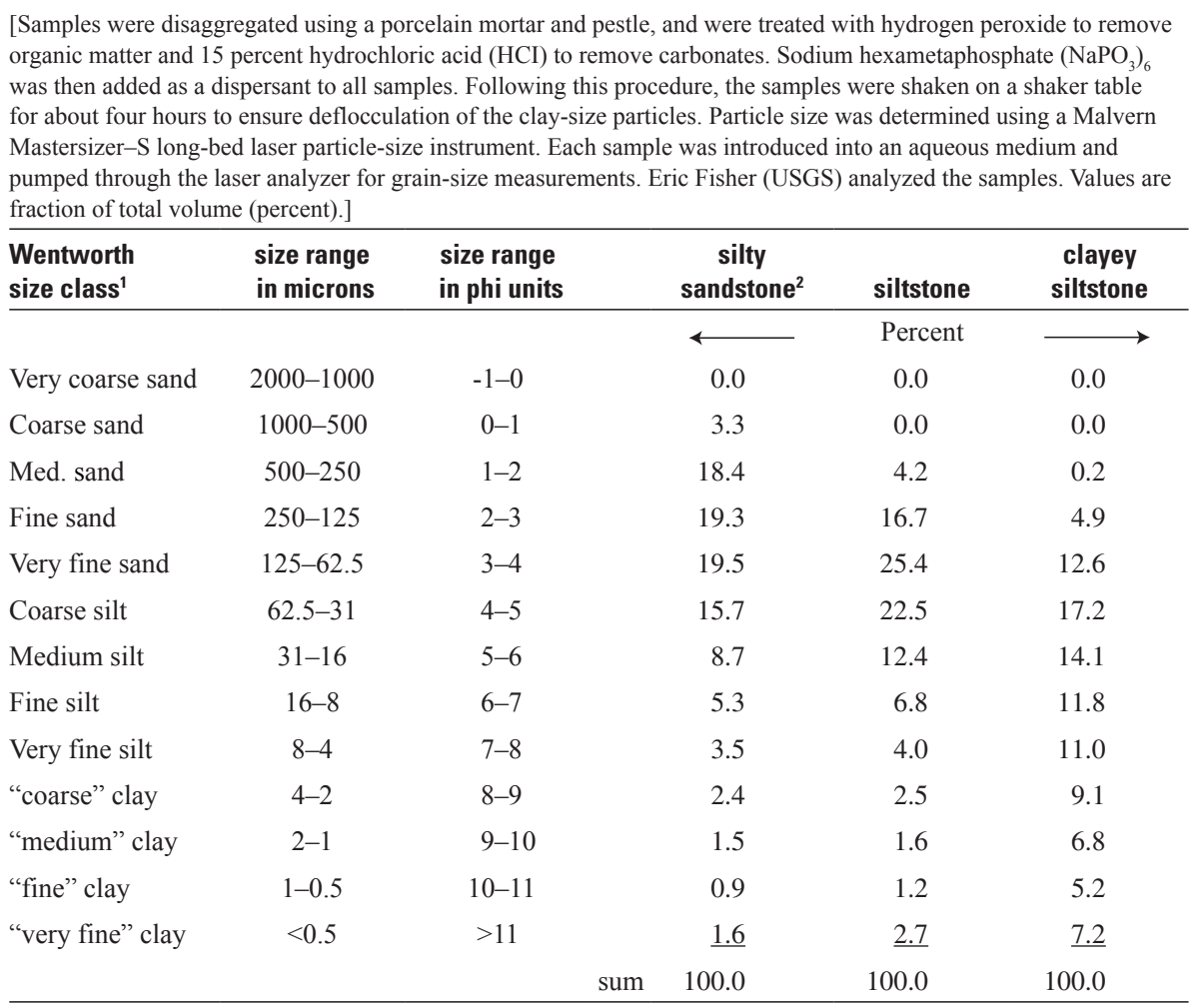

${ }^{1}$ Size ranges are those of the Wentworth scale (Folk, 1965). Terms in quotation marks are informal terminology.

${ }^{2}$ Lithologic designations are based on field descriptions.

(gravity-driven) processes - such as creep, debris flow, and rock fall that are locally aided by running water not confined to channels.

Surficial map units that include debris-flow deposits probably also include hyperconcentrated-flow deposits. These latter deposits have bedding and sorting characteristics intermediate between those of stream-flow and debris-flow deposits (Pierson and Costa, 1987; Meyer and Wells, 1997).

In this report, the terms "soil" and "soils" refer to pedogenic soils formed in surficial deposits. Soil-horizon designations are those of the Soil Survey Staff (1999) and Birkeland (1999). Colors of soil horizons, surficial deposits, and siltstone of the Troublesome Formation (NPet) are for air-dried samples, and were determined with the aid of Munsell soil color charts (Munsell Color, 1973).

Subsurface lithologic data referred to in this report were obtained from driller's logs on file with the Colorado Division of Water Resources (Colorado Division of Water Resources, 2007).

Most of the bedrock in the Fraser quadrangle is poorly exposed. A thin mantle of unmapped colluvium (Qcs) locally overlies large areas of Proterozoic rock in the southern and eastern parts of the quadrangle. In these and other parts of the map area, the Troublesome Formation (NPt) and rhyolite tuff $\left(P_{\varepsilon t}\right)$ are concealed locally by deposits of unmapped colluvium (Qcc) derived chiefly from the Troublesome.
Descriptions of Proterozoic units are in part modified from those of Kellogg and others (2008), and are based in part on petrographic studies in the Strawberry Lake quadrangle (fig. 1) north of the Fraser quadrangle (Schroeder, 1995a) and in Vasquez Peak Wilderness Area and nearby roadless areas south and southwest of the Fraser quadrangle (Eppinger and others, 1985).

In this report, "migmatite" refers to biotite gneiss containing numerous layers and irregular pods of light-gray or white granitic rock (leucosomes), typically $1-5 \mathrm{~cm}$ thick but locally thicker, which in some places are strongly folded along with the enclosing biotite gneiss. Formation of leucosomes is generally attributed to partial melting of the biotite gneiss during metamorphism (Olsen, 1982; Johannes and Gupta, 1982; Cole and Braddock, 2009). The term "Laramide" (orogeny) refers to a protracted period of basement faulting, folding, magmatic activity, and regional uplift between Late Cretaceous and early Eocene across the southern Rocky Mountains (Tweto, 1975).

The community that was named Hideaway Park is now part of the town of Winter Park Colo., and the name has been removed from the base map used in this report. In keeping with current usage, the name Winter Park is used in this report.

The ski area, about $3 \mathrm{~km}$ south of the old Hideaway Park area (now labeled Winter Park), is referred to as the Winter Park Ski Area. 


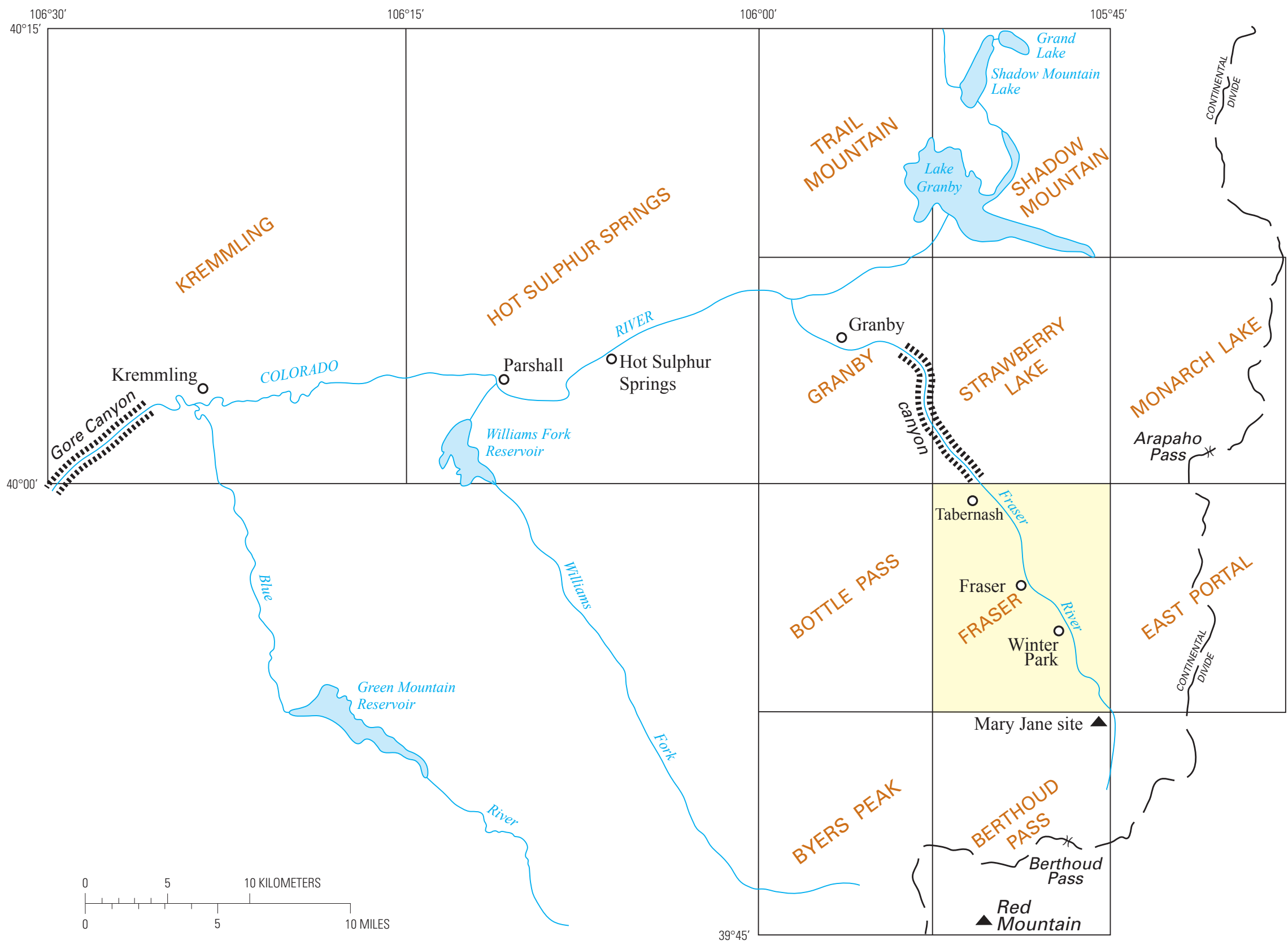

Figure 1. Index of 7.5- and 15-minute quadrangles referred to in this report. Fraser 7.5-minute quadrangle in yellow. Canyons are depicted with black hachures. Dashed black line is the Continental Divide. 


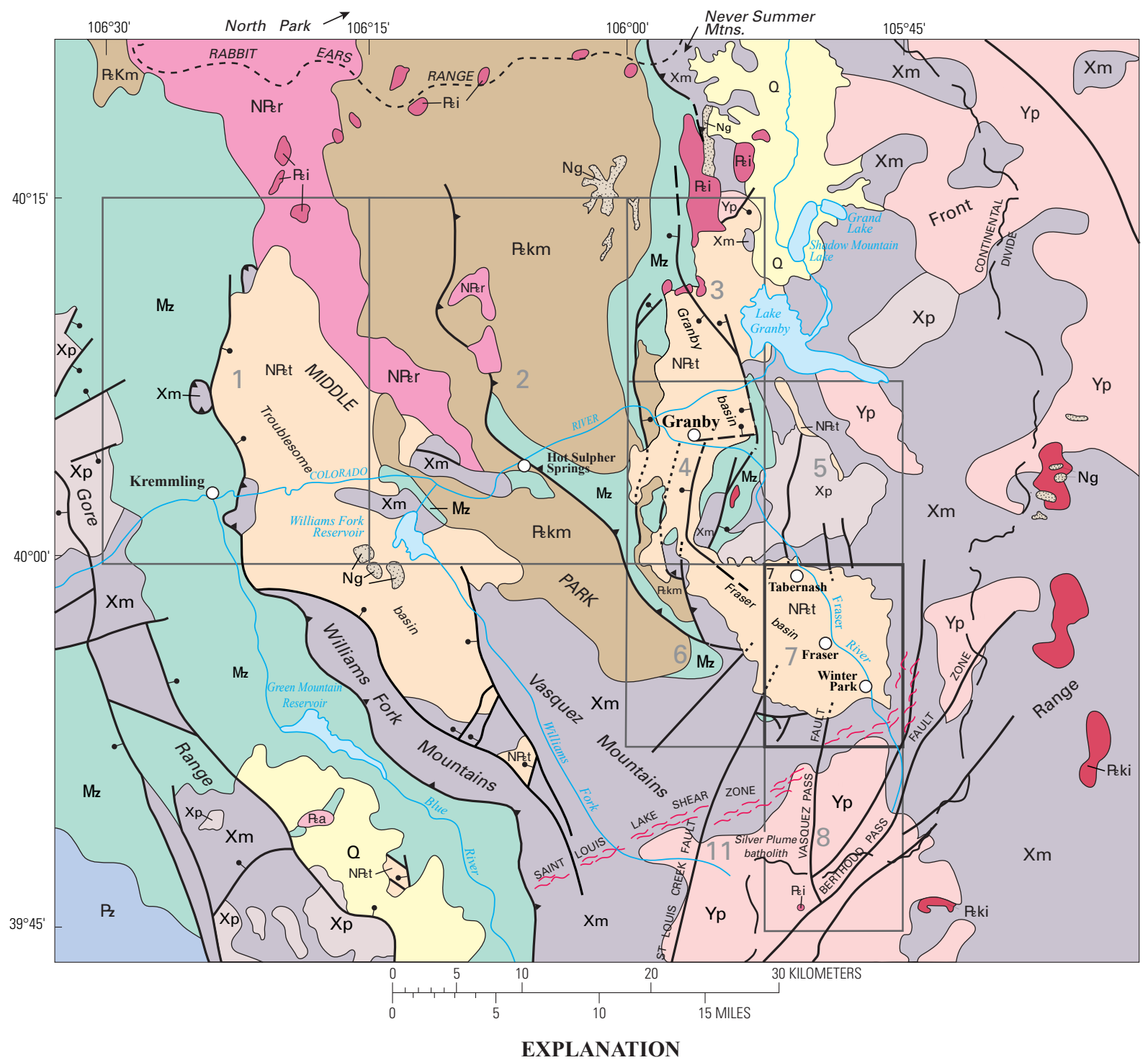

\begin{tabular}{|c|c|c|c|}
\hline 0 & Surficial deposits (Quaternary)—Mostly till and outwash & Yp & Mesoproterozoic plutonic rocks \\
\hline Ng: & Gravel (Pliocene? and Miocene) & $X p$ & Paleoproterozoic plutonic rocks \\
\hline Pea & Trachyandesite flows (late Oligocene) & $\mathrm{Xm}$ & Paleoproterozoic metamorphic rocks and small \\
\hline$N P_{t} t$ & Troublesome Formation (Miocene and upper Oligocene) & & Contact \\
\hline$N P_{\varepsilon} r$ & Rabbit Ears Volcanics (early Miocene? and Oligocene) & ค & Normal Fault with Neogene movement-Bar and \\
\hline $\mathrm{Pe}_{\mathrm{i}}$ & Latite and rhyolite plutons (Oligocene) & & $\begin{array}{l}\text { ball on downthrown side. Dashed where approximate, } \\
\text { dotted where concealed }\end{array}$ \\
\hline Pekm & Middle Park Formation (Paleocene and Upper Cretaceous?) & & $\begin{array}{l}\text { Thrust or reverse fault with inferred Laramide } \\
\text { movement-Teeth on upthrown side. Dashed where }\end{array}$ \\
\hline Peki & Laramide plutons (Paleocene and Late Cretaceous) & & Fault_ unsnecified-Mostly Laramide Dashed where \\
\hline $\mathrm{Mz}$ & Mesozoic sedimentary rocks & & approximate, dotted where concealed \\
\hline $\mathrm{P}_{2}$ & Paleozoic sedimentary rocks & & Continental Divide \\
\hline
\end{tabular}

Figure 2. Regional geologic setting of parts of the Front and Gore Ranges and adjacent basins. Quadrangles and corresponding geologic maps are as follows: (1), Kremmling, 15 minute (Izett and Barclay, 1973); (2) Hot Sulphur Springs 15 minute (Izett, 1968); (3) Trail Mountain (Izett, 1974); (4) Granby (Schroeder, 1995b); (5) Strawberry Lake (Schroeder, 1995a); (6) Bottle Pass (Taylor, 1975); (7) Fraser (this report); and (8) Berthoud Pass (Theobald, 1965). Oligocene age of trachyandesite flows south of Green Mountain Reservoir is based on ${ }^{40} \mathrm{Ar} /{ }^{39} \mathrm{Ar}$ sanidine ages of two of these flows dated 23.62 $\pm 0.6 \mathrm{Ma}$ and $23.63 \pm 0.06 \mathrm{Ma}$ (Naeser and others, 2002). 


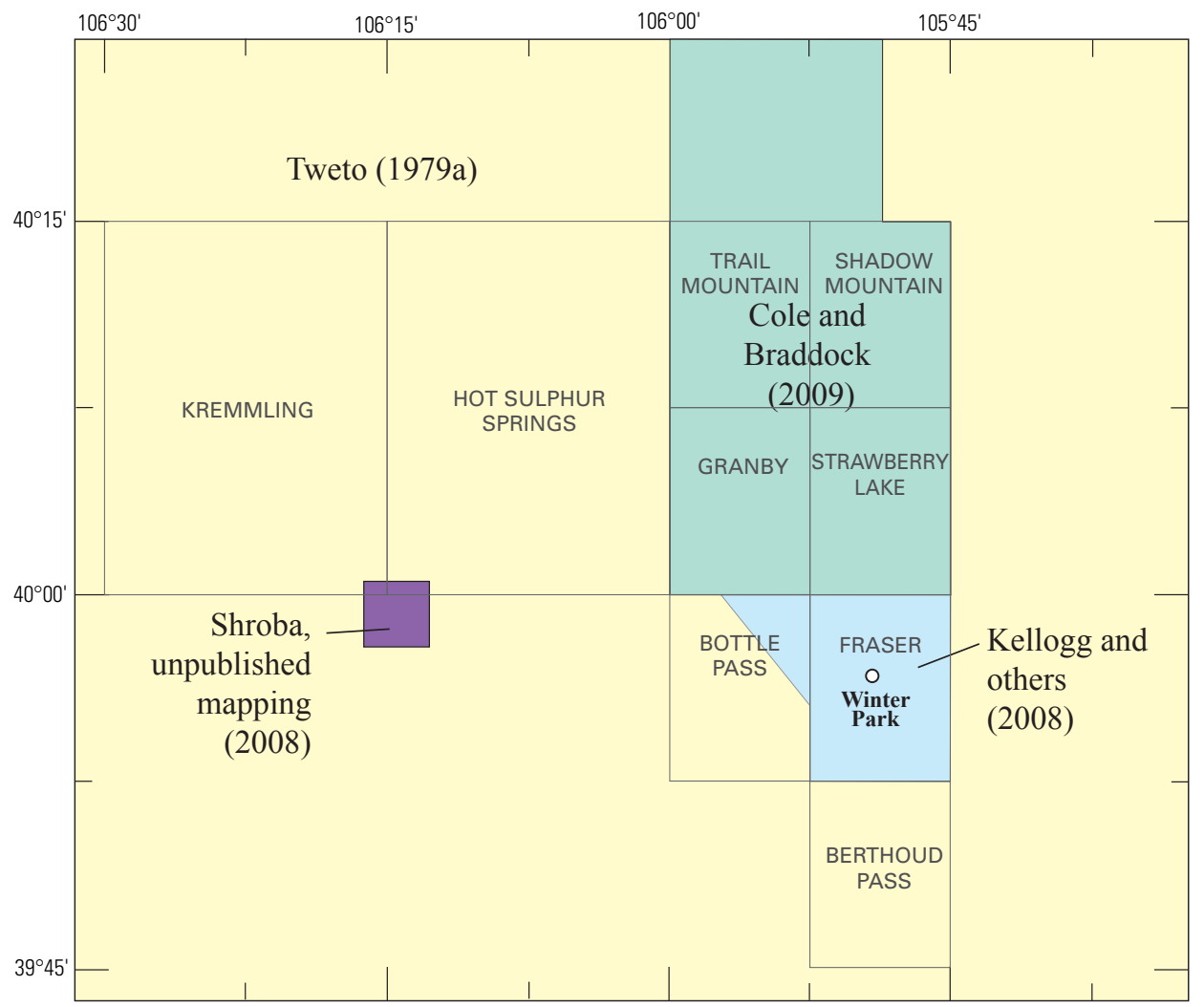

Figure 3. Index of geologic mapping in figure 2.

\section{Description of Map Units}

\section{Surficial Deposits}

\section{Artificial Fill Deposits}

Artificial fill (latest Holocene) - Compacted fill material composed mainly of silt, sand, and rock fragments.

Mapped beneath railroad tracks near the Winter Park Ski Area and the town of Tabernash, Colo., the highway US 40 overpass east of Tabernash, and parking lots and man-made structures at the Winter Park Ski Area.

Distribution based on interpretation of color aerial photographs taken in 2000. Estimated thickness is $1-10 \mathrm{~m}$

\section{Alluvial Deposits}

Valley-floor alluvium (Holocene and late Pleistocene?) - Mostly poorly sorted coarse sand and pebbly to cobbly gravel in stream channels and flood plains along the Fraser River and streams in glaciated tributary drainages where it probably overlies, and locally may include, gravelly stream-terrace alluvium $\left(\mathrm{Og}_{1}\right)$. Unit Qva probably consists mostly of poorly sorted sand and gravel along non-glaciated tributary streams and locally contains a significant amount of silty alluvium in areas underlain by the Troublesome Formation (NPt). Locally may include organic-rich sediments in marshes and other wet areas. The depositional top of the unit is commonly less than $5 \mathrm{~m}$ above the Fraser River and its major tributary streams near the towns of Fraser and Tabernash, Colo. Gravel deposits along Fraser River and glaciated tributary streams are potential sources of coarse aggregate. Low-lying deposits are prone to periodic stream flooding. Estimated thickness is 1-5 m 
Qsa

Sheetwash deposits and valley-floor alluvium, undivided (Holocene and late Pleistocene?) - Chiefly silty and sandy sheetwash deposits (Qsw) on gentle slopes and a minor amount of undifferentiated sandy and pebbly valley-floor alluvium (Qva) along and near ephemeral streams along the south side of Ranch Creek, in the northeast part of the map area. Low-lying areas of unit Qsa in and adjacent to stream channels may be subject to periodic stream flooding, gullying, and possibly debris-flow deposition; adjacent slopes may be subject to periodic sheet flooding due to sheet flow. Estimated thickness is $1-5 \mathrm{~m}$

\section{Qsw}

Sheetwash deposits (Holocene and late Pleistocene) - Pebbly, slightly silty sand to sandy, clayey silt derived chiefly from Troublesome Formation (NPt) and Proterozoic bedrock along Ranch Creek; mostly sandy, clayey silt derived chiefly from the Troublesome Formation along Elk Creek in the southwest part of the map area. Low-lying areas of unit Qsw may be subject to sheet flooding due to sheet flow, and locally to stream flooding and gullying. Estimated thickness is $1-5 \mathrm{~m}$

Gravelly stream-terrace alluvium (late to early? Pleistocene)—Glacial outwash gravel deposited chiefly by the Fraser River and its major tributaries Saint Louis Creek and Ranch Creek during two or more glaciations as well as fluvial gravel of non-glacial origin along streams tributary to the Fraser River that head in nonglaciated drainage basins. Some of the fluvial gravel of non-glacial origin may be coeval with glacial episodes. Units $\mathrm{Qg}_{1}$ through $\mathrm{Qg}_{8}$ are subdivided based on height above present stream level (table 2).

$\mathrm{Og}_{1} \quad$ Unit 1 (late Pleistocene)_Glacial outwash composed of poorly sorted, clast-supported, cobbly pebble gravel deposited by meltwater streams during the Pinedale glaciation and fluvial gravel of non-glacial origin on the north side of Pole Creek near Tabernash. The unit locally contains lenses of pebble gravel, pebbly sand, and fine to medium sand about $15-40 \mathrm{~cm}$ thick. Deposits near outer limit of glaciation locally contain a few small boulders about $25-50 \mathrm{~cm}$ in diameter. Large pebbles and cobbles commonly are subangular and subrounded granite and gneiss; some are rounded. Matrix is mostly coarse to very coarse sand that is unoxidized (10YR 7/2) at a depth of $>1 \mathrm{~m}$. Thin $(20-35 \mathrm{~cm})$ overbank sediments composed of slightly pebbly silty sand and locally sandy silt and sandy clayey silt locally overlie the gravel. Fluvial deposits of non-glacial origin on the north side of Pole Creek, about $1 \mathrm{~km}$ southwest of Tabernash, consist of slightly cobbly pebble gravel overlain by about $35 \mathrm{~cm}$ of slightly pebbly, sandy, clayey silt overbank sediment. Unit underlies one and locally two terrace treads, and probably locally underlies valley-floor alluvium (Qva). Terrace treads are about 6 and $12 \mathrm{~m}$ above the Fraser River near the towns of Winter Park and Fraser; about $6 \mathrm{~m}$ above the Fraser River near Tabernash and Saint Louis Creek near Fraser; about 6-9 m above Ranch Creek; and about $6 \mathrm{~m}$ above Crooked Creek and Pole Creek (table 2). Unit locally may include a minor amount of valley-floor alluvium (Qva). Unit $\mathbf{Q g}_{1}$ is a potential major source of coarse aggregate. Deposits of unit $\mathbf{Q g}_{1}$ in glaciated valleys are composed of glacial outwash deposited during the Pinedale glaciation, about 12-30 ka (Nelson and others, 1979; Madole, 1986; Benson and others, 2004, 2005). Cosmogenic dating of Pinedale outwash, 4-14 $\mathrm{m}$ above stream level in Boulder Canyon east of Nederland, Colorado, yielded surface-exposure ages of 10-32 ka (Schildgen and others, 2002). Unit thickness decreases in a downstream direction; estimated thickness along the Fraser River about $10 \mathrm{~m}$ near Winter Park and Fraser, and about 1-2 m near Tabernash

$\mathrm{Og}_{2}$

Unit 2 (late and middle Pleistocene) - Glacial outwash composed of poorly to moderately well sorted, clastsupported, cobbly pebble gravel deposited by meltwater streams during the Bull Lake glaciation and fluvial deposits of non-glacial origin along Crooked Creek near Tabernash. The unit locally contains lenses of pebble gravel, pebbly granule-rich sand, and sand. Deposits near outer limit of glaciation, locally contain a few small boulders about $25-35 \mathrm{~cm}$ in diameter and are rarely as large as 70-120 $\mathrm{cm}$ in diameter. Large pebbles and cobbles commonly are subangular and subrounded granite and gneiss; some are rounded and well rounded. Matrix is mostly coarse to very coarse sand that is slightly oxidized (10YR 7/4). Pebbly sand or sandy silt overbank sediments, about 1-3 m thick, locally overlie the gravel. Unit underlies till of the Bull Lake glaciation (Otb) about $0.5 \mathrm{~km}$ north of Vasquez Creek in Winter Park. Fluvial deposits of non-glacial origin along Crooked Creek, about $3 \mathrm{~km}$ southwest of Tabernash, consist of slightly cobbly pebble gravel overlain by about $2.5-3 \mathrm{~m}$ of slightly pebbly and cobbly, sandy, clayey silt overbank sediment that contains lenses of cobbly pebble gravel. Unit underlies one and locally two terrace treads about $24 \mathrm{~m}$ above the Fraser River near Winter Park and Fraser; about 12 and $18 \mathrm{~m}$ above the Fraser River east of Tabernash; about $12 \mathrm{~m}$ above Saint Louis Creek near Fraser; about $18 \mathrm{~m}$ above Crooked Creek; and about 18-24 m above Ranch Creek (table 2). About $15 \mathrm{~km}$ downstream of Tabernash at Granby, Colo. (fig. 1), glacial outwash of Bull Lake age underlies a terrace tread about $12 \mathrm{~m}$ above the Fraser River (Meierding, 1977). The soil that formed in pebbly alluvium beneath the 12-m high, fan-shaped terrace along Saint Louis Creek west of Fraser has a brown (7.5YR 5/4) argillic B (Bt) horizon $35 \mathrm{~cm}$ thick. Deposits of unit $\mathrm{Qg}_{2}$, about $3 \mathrm{~km}$ northwest of Fraser, are a major source of sand and gravel for construction and other uses. The proximity of till of the Bull Lake glaciation ( $\mathrm{Qtb}$ ) to outwash terraces underlain by unit $\mathrm{Qg}_{2}$ suggests that unit $\mathrm{Qg}_{2}$ was deposited by 
glacial meltwater during the Bull Lake glaciation (about 120-170 ka; Sharp and others, 2003; Pierce, 2004). Recent cosmogenic dating of Bull Lake outwash, $16 \mathrm{~m}$ above stream level in Boulder Canyon east of Nederland, Colo., yielded a surface-exposure age of $130 \mathrm{ka}$ (Schildgen and others, 2002). Estimated thickness is $10 \mathrm{~m}$ along the Fraser River near Winter Park, and $5 \mathrm{~m}$ downstream near Tabernash; 18-20 m along Saint Louis Creek near Fraser; and 3-6 m along Ranch Creek and Crooked Creek

$\mathrm{Og}_{3} \quad$ Unit 3 (middle Pleistocene) — Probably glacial outwash composed of poorly sorted, clast-supported, cobbly pebble gravel deposited by meltwater streams during a pre-Bull Lake glaciation. The unit locally contains lenses of pebble gravel, pebbly sand, and sand. Large pebbles and cobbles commonly are subangular and subrounded granite and gneiss; some are rounded. Cobbles are commonly as large as $15-25 \mathrm{~cm}$ in diameter. Matrix is mostly coarse to very coarse sand that is slightly (10YR 7/4) to strongly oxidized (10YR 6/6). Overbank sediments composed of pebbly sand or clayey silt, about $1 \mathrm{~m}$ thick, locally overlies the gravel. Probably much of this clayey silt is derived from siltstone of the Troublesome Formation (NRet). A small deposit of pink (7.5YR 6/4) sandy (mostly very fine to fine sand) silt, too small to show on the map, mantles a low east-facing fluvial scarp at the eastern boundary of unit $\mathrm{Qg}_{3}$, about $1 \mathrm{~km}$ south of Tabernash. This sandy silt probably is eolian sediment (loess) deflated from nearby flood plains, possibly during the Pinedale glaciation. Unit consists of six terrace and stream-channel deposits about $30 \mathrm{~m}$ above the Fraser River south and southeast of Fraser; about $35 \mathrm{~m}$ above the Fraser River near Tabernash; and about 30-35 m above Ranch Creek east of Fraser (table 2). Estimated thickness is $10 \mathrm{~m}$ near Fraser and 8-10 m south of Tabernash

$\mathrm{Og}_{4} \quad$ Unit 4 (middle Pleistocene) — Probably glacial outwash composed of poorly sorted, clast-supported, cobbly pebble gravel deposited by meltwater streams during a pre-Bull Lake glaciation, as well as fluvial gravel of non-glacial origin along Spring Branch (tributary of Crooked Creek). The unit locally contains lenses of pebble gravel, pebbly, granule-rich sand, and sand. Deposits near Fraser locally contain a few small boulders about $25-35 \mathrm{~cm}$ in diameter. Large pebbles and cobbles commonly are subangular and subrounded granite and gneiss. Cobbles are commonly as large as $20 \mathrm{~cm}$ in diameter. Matrix is mostly coarse to very coarse sand. Overbank sediment, about 1-1.5 m thick, composed of (1) slightly pebbly, silty, mostly very fine to medium sand as well as (2) slightly pebbly, sandy, clayey silt locally overlies the gravel. Unit consists of small terrace and probably stream-channel deposits about 50-55 m above the Fraser River east and southeast of Fraser, along Ranch Creek northeast of Fraser, and along Spring Branch southwest of Fraser (table 2). Estimated thickness is $16 \mathrm{~m}$ east of Fraser and $3 \mathrm{~m}$ or more along Ranch Creek

$\mathrm{Og}_{5} \quad$ Unit 5 (middle Pleistocene) - Fluvial gravel of non-glacial origin and possibly glacial outwash composed of slightly cobbly pebble gravel deposited during a pre-Bull Lake glaciation. Large pebbles and cobbles commonly are subangular and subrounded granite and gneiss. Cobbles are commonly as large as $10 \mathrm{~cm}$ in diameter. Matrix is mostly coarse to very coarse sand. Unit consists of three small terrace or steam-channel deposits about $65 \mathrm{~m}$ above the Fraser River southeast of Tabernash; about $65 \mathrm{~m}$ above Ranch Creek northeast of Fraser; and about $60 \mathrm{~m}$ above Pole Creek west of Tabernash (table 2). The deposits southeast of Tabernash and northeast of Fraser may have accumulated along a former course of Ranch Creek. Estimated thickness is 5-10 m Unit 6 (middle Pleistocene) -Fluvial gravel of non-glacial origin and possibly glacial outwash composed of slightly bouldery, cobbly, pebble gravel deposited during a pre-Bull Lake glaciation. Large pebbles and cobbles commonly are subangular and subrounded granite and gneiss. Cobbles are commonly as large as $20-25 \mathrm{~cm}$ in diameter; boulders are as large as $50 \mathrm{~cm}$ in diameter. Matrix is mostly coarse to very coarse sand. Unit consists of two terrace or stream-channel deposits about 85-90 m above the Fraser River, southeast and northeast of Fraser (table 2). A stream tributary to the Fraser River, possibly a former course of Ranch Creek, deposited the alluvium northeast of Fraser. Estimated thickness is 5-10 m

$\mathrm{Og}_{7} \quad$ Unit 7 (middle or early Pleistocene)—Fluvial gravel of non-glacial origin composed of cobbly pebble gravel that was deposited by streams tributary to the Fraser River, possibly during a pre-Bull Lake glaciation. The upper part of the unit locally consists of matrix-supported, slightly pebbly and cobbly, slightly sandy, clayey silt. The clayey silt probably was derived chiefly from siltstone of the Troublesome Formation (NPEt). Unit locally contains a few small boulders about $35-45 \mathrm{~cm}$ in diameter that are composed of granite, gneiss, and sandstone probably derived from the Dakota Group $(\mathrm{Kd})$ as well as a few rounded red (10R) siltstone pebbles that may have been eroded from the Morrison Formation $(\mathrm{Jm})$. Cobbles are commonly as large as $10-25 \mathrm{~cm}$ in diameter. Large pebbles and cobbles commonly are subangular granite and gneiss along with a minor amount of sandstone probably derived from the Dakota Group. Matrix of gravel deposits is mostly coarse to very coarse sand. Unit consists of four small stream-channel(?) deposits about 105-115 m above the Fraser River northeast and southeast of Fraser (table 2). Estimated thickness is 3-10 m

$\mathrm{Og}_{8} \quad$ Unit 8 (middle or early Pleistocene)—Fluvial gravel of non-glacial origin or possibly glacial outwash composed of poorly sorted, clast supported, slightly bouldery, cobbly pebble gravel deposited by the Fraser River, 
during a pre-Bull Lake glaciation. The unit locally contains (1) lenses of granule-rich, medium to very coarse sand; (2) a minor amount of boulders about $25-120 \mathrm{~cm}$ in diameter composed of granite, pegmatite, and sandstone probably derived from the Dakota Group (Kd); (3) a few rounded rhyolite ( $\left.\mathrm{P}_{\varepsilon} \mathrm{t}\right)$ and red (10R) siltstone pebbles (possibly eroded from the Morrison Formation, ( $\mathrm{Jm}$ ); and (4) rare conglomerate clasts derived from the Troublesome Formation (NPt). Large pebbles and cobbles commonly are subangular and subrounded granite and gneiss as well as a minor amount of subangular pegmatite and sandstone probably derived from the Dakota Group. Cobbles are commonly as large as $25 \mathrm{~cm}$ in diameter. Matrix is poorly sorted, mostly coarse to very coarse sand that contains abundant granules; unoxidized matrix is pinkish gray (7.5YR 7/2). Unit consists of two terrace or stream-channel deposits about $145 \mathrm{~m}$ above the Fraser River about $1.5 \mathrm{~km}$ northeast and southeast of Winter Park (table 2). Thickness is about $2-12 \mathrm{~m}$

$\mathrm{QNg}$

Old gravelly stream alluvium (early Pleistocene or Pliocene) - Unit consists of two poorly exposed slightly bouldery deposits that overlie Proterozoic bedrock, and locally Troublesome Formation (NPt), on high ridges near the southeast corner of the map area. Deposits consist of poorly sorted, matrix-supported and clast-supported, slightly bouldery, cobbly pebble fluvial gravel. These deposits probably contain lenses of pebble gravel and sand. Matrix is mostly coarse to very coarse sand that contains abundant granules. Large pebbles and cobbles commonly are subangular and subrounded granite and gneiss. Boulders are composed chiefly of granite, gneiss, and pegmatite, as well as a minor amount of sandstone probably derived from the Dakota Group (Kd) that are commonly as long as $50-170 \mathrm{~cm}$. Deposits contain a few rounded red (10R) siltstone pebbles probably eroded from the Morrison Formation ( Jm). Top of unit is about 245-270 $\mathrm{m}$ above the Fraser River southeast of Winter Park (table 2). Unit QNg may be correlative with the boulder conglomerate of Pliocene(?) age in the nearby Trail Mountain quadrangle (Izett, 1974). Estimated thickness is 5-10 m

\section{Alluvial and Mass-Movement Deposits}

Qac

Qf

$\mathrm{Op}_{1}$

$\mathrm{Op}_{2}$

Alluvium and colluvium, undivided (Holocene and late Pleistocene) - Chiefly undifferentiated valley-floor alluvium (Qva) along minor streams and colluvium (Qcc and Qcs) on adjacent slopes. Matrix of colluvial deposits is sandy (Qcs) in areas where deposits are derived chiefly from Proterozoic bedrock, and rich in silt (Qcc) where derived chiefly from the Troublesome Formation (NPEt). Low-lying areas of the unit adjacent to stream channels may be subject to periodic stream flooding and debris-flow deposition; sloping areas outside of stream channels may be subject to periodic sheet flooding due to sheet flow. Estimated thickness is $1-5 \mathrm{~m}$

Fan deposits (Holocene and late Pleistocene) - Non-sorted to poorly sorted, fan-shaped masses composed chiefly of pebble-and-cobble gravel and silty sand southeast of Tabernash and bouldery, pebble-and cobblegravel northwest of the Winter Park Ski Area. Deposited chiefly by debris flow, stream flow, and probably by hyperconcentrated flow. Deposits southeast of Tabernash locally may include clayey-silt matrix colluvium (Qcc). Low-lying areas of the unit may be subject to debris-flow deposition and stream flooding. Estimated thickness is $3-15 \mathrm{~m}$

Lower pediment deposits (late Pleistocene) - Crudely stratified, matrix-supported small boulders to granules in a sandy, clayey silt matrix overlies northeast sloping surface formed on Troublesome Formation (NPEt) on the west side of Crooked Creek southwest of Tabernash. Matrix makes up much of the unit, and is chiefly derived from siltstone of the Troublesome Formation. Unit probably deposited chiefly by debris flows, hyperconcentrated flows, and ephemeral streams under periglacial conditions probably during the Pinedale glaciation. Large pebbles and cobbles commonly are angular to subangular and consist of sandstone probably derived from the Dakota Group (Kd), gneiss, and pegmatite. Sandstone boulders are commonly as long as $50 \mathrm{~cm}$. Lower limit of unit is about $6 \mathrm{~m}$ above Crooked Creek. Estimated thickness is $2-5 \mathrm{~m}$

Higher pediment deposits (late and middle Pleistocene) - Crudely stratified, matrix-supported small boulders to granules in a sandy, clayey silt matrix that overlies a northeast sloping surface formed on Troublesome Formation (NPt) on the west side of Crooked Creek southwest of Tabernash. Matrix makes up much of the unit, and is chiefly derived from siltstone of the Troublesome Formation. Unit probably deposited chiefly by debris flows, hyperconcentrated flows, and ephemeral streams under periglacial conditions probably during the Bull Lake glaciation. Large pebbles and cobbles commonly are angular to subangular and consist of sandstone probably derived from the Dakota Group $(\mathrm{Kd})$, gneiss, pegmatite, and locally a minor amount of porphyritic andesite probably derived from the Middle Park Formation in the adjacent Bottle Pass quadrangle (Taylor, 1975) on the west side of the map area (fig. 1). Boulders composed of sandstone and locally volcanic porphyry are commonly as long as $40 \mathrm{~cm}$. Lower limit of unit is about $12-18 \mathrm{~m}$ above Crooked Creek. Eastern margin of unit locally includes cobbly fluvial gravel $\left(\mathrm{Og}_{2}\right)$. Estimated thickness is $2-5 \mathrm{~m}$ 
Qgd Gravelly stream alluvium and diamicton, undivided (middle Pleistocene) - Unit consists of very poorly exposed slightly bouldery deposits that overlie the Troublesome Formation (NPt), and locally rhyolite tuff $\left(\mathrm{P}_{\mathrm{t}}\right)$, on five high ridges and hills beyond the outer limit of till of the Pinedale glaciation (Qtp) a few kilometers south of Fraser. Deposits southeast of Fraser consist of fluvial gravel, and probably locally include bouldery debris-flow deposits. The fluvial gravel is poorly sorted, matrix-supported and clast-supported, slightly bouldery, cobbly pebble gravel. It probably contains lenses of pebble gravel and sand. Matrix is mostly coarse to very coarse sand that contains abundant granules. Large pebbles and cobbles commonly are subangular and subrounded granite and gneiss. Boulders composed of granite, gneiss, pegmatite, and sandstone probably derived from the Dakota Group (Kd) are commonly as large as $25-60 \mathrm{~cm}$ in diameter and as long as $40-100 \mathrm{~cm}$. The gravel contains a few rounded red (10R) siltstone pebbles probably eroded from the Morrison Formation (Jm). Deposits south and southwest of Fraser consist of (1) fluvial gravel — possibly glacial outwash - deposited by Saint Louis Creek and Elk Creek, and (2) locally till-like deposits (diamictons composed of till or debris-flow deposits) that may have been deposited during one or more pre-Bull Lake glaciations. Fluvial gravel consists of poorly sorted, granite-rich, slightly bouldery, cobbly, pebble gravel. Matrix is mostly coarse to very coarse sand that contains abundant granules. Large pebbles and cobbles commonly are subangular; boulders are commonly as large as $25-40 \mathrm{~cm}$ in diameter and as long as $50-80 \mathrm{~cm}$. Till-like deposits are locally present at elevations of about 2,830-2,920 m along Elk Creek. These deposits contain granite and gneiss boulders as long as 1-2 m. On slopes steeper than about 6 degrees, unit locally may include colluvium composed of clasts derived from fluvial gravel and till-like deposits, and matrix derived chiefly from siltstone of the Troublesome Formation. Some of the colluvium may be of late Pleistocene age. Top of unit is about 90-180 m above the Fraser River, about 85-110 m above Elk Creek, and about 50-195 m above Saint Louis Creek. Estimated thickness of fluvial gravel is 5-15 m; till-like deposits 5-10 m

\section{Mass-Movement Deposits}

Qcc Clayey-silt matrix colluvium (Holocene to middle? Pleistocene) - Non-sorted, matrix-supported, boulders to granules in a light brown (7.5YR 6/4) very plastic, sandy, clayey to very clayey silt matrix. The matrix is derived chiefly from siltstone of the Troublesome Formation (NPt). Granules and larger clasts commonly are angular to subangular and make up about 20-60 percent of the deposits. Boulders composed of granite, pegmatite, and sandstone probably derived from the Dakota Group $(\mathrm{Kd})$ commonly are as large as 25-90 $\mathrm{cm}$ in diameter. Deposits locally contain angular to subangular clasts of rhyolite tuff $\left(\mathrm{Pet}_{\mathrm{t}}\right)$ as long $50 \mathrm{~cm}$. Granules and larger clasts commonly derived from surficial deposits and bedrock farther upslope. Unit probably deposited chiefly by creep and commonly overlies siltstone of the Troublesome Formation. Estimated thickness is $1-5 \mathrm{~m}$

Qcs Sandy matrix colluvium (Holocene to middle? Pleistocene) - Non-stratified to crudely stratified, mostly matrix-supported, boulders to granules in a matrix of very pale brown (10YR 7/3) slightly silty, poorly sorted, mostly medium to very coarse sand. Granules and larger clasts are commonly angular to subangular and make up about 20-75 percent of the deposits. Boulders are commonly as long as 50-100 cm. Clasts and matrix are derived chiefly from Proterozoic bedrock farther upslope. Unit probably deposited chiefly by creep, debris flow, and locally by sheet flow; commonly is downslope of, and overlies, Proterozoic bedrock. Estimated thickness is $1-5 \mathrm{~m}$

Landslide deposits (Holocene to middle? Pleistocene) - Deposits of unsorted and unstratified debris that commonly display hummocky topography. Many of the landslides and landslide deposits form on unstable slopes that are underlain by either (1) weakly consolidated siltstone of the Troublesome Formation (NPt) along and near the major streams or (2) till (or stratified drift) of Pinedale age (Qtp) on the west side of Vasquez Creek. Sliding of the Troublesome Formation may be locally due in part to abundant clay formed by the alteration of volcanic ash. Younger landslide deposits are commonly bounded upslope by crescent-shaped headwall scarps and downslope by lobate toes. A few of the younger landslide deposits, such as the large landslide deposit on the east side of Saint Louis Creek, locally constrict flood plains and overlie valley-floor alluvium (Qva). Unit Qls locally includes material displaced chiefly by debris slides, and possibly by earth flows, and earth slide-earth flows as defined by Varnes and Cruden (1996). Some deposits probably are formed by translational slides and by rock or earth creep. The sizes and lithologies of the clasts and the grain-size distributions of the matrices of these deposits reflect those of the displaced bedrock units and surficial deposits farther upslope. Landslide deposits are prone to continued movement or reactivation due to both natural and humaninduced processes. Deposits on gentle slopes locally include minor sheetwash (Qsw) and creep-deformed deposits. Estimated thickness is $5-50 \mathrm{~m}$ 
Qta

Talus deposits (Holocene to middle? Pleistocene) - Unit consists of two deposits composed chiefly of angular tabular blocks of rhyolite tuff $\left(\mathrm{P}_{\mathrm{\varepsilon t}}\right)$, deposited chiefly by rock fall and rock creep, at the base of weakly welded rhyolite tuff about $0.5 \mathrm{~km}$ east and about $4 \mathrm{~km}$ southwest of Winter Park. Clasts commonly range in size from about $2 \times 2 \times 2 \mathrm{~cm}$ to as large as about $30 \times 60 \times 110 \mathrm{~cm}$. The toe of the deposit east of Winter Park has ridges and furrows that formed where creep remobilized the lower part of the deposit. The long axes of some clasts near the toe of the deposit are nearly vertical. Black and green lichens cover exposed surfaces of clasts at the top of the deposit east of Winter Park; some clasts have impact scars. The upper part of this deposit near the toe has open voids that extend to a depth of $1.7 \mathrm{~m}$. At a greater depth, the matrix is pink (7.5YR 7/4) sandy silt and locally coarse sand that contains granules and small pebbles. Coarse sand and larger fragments are composed of rhyolite tuff. Silt in the matrix may be derived from siltstone of the Troublesome Formation (NPt) or may be eolian silt derived from current or former flood-plain deposits. Estimated thickness is $3-10 \mathrm{~m}$

\section{Glacial Deposits}

Till of Pinedale age (late Pleistocene) - Mostly non-sorted and non-stratified, subangular and subrounded boulders to granules in a slightly silty to silty, sand matrix. Clasts are commonly angular to subangular and make up about 40-80 percent of the deposits. Boulders composed of granite, gneiss, and pegmatite commonly are 1-2 $\mathrm{m}$ long; some are as long as 2.5-4.5 m. Most of the biotite-rich pebbles and cobbles composed of granite, gneiss, and schist within the surface soil and oxidized till are unweathered and disintegrated clasts are rare. Material less than $2 \mathrm{~mm}$ in diameter makes up about 20-60 percent of the deposits, and consists chiefly of medium to very coarse sand and probably about $\leq 20$ percent silt and $\leq 5$ percent clay. Unit is oxidized (10YR 6/3 or 10YR7/3) to a depth of about $2 \mathrm{~m}$; unoxidized matrix is light gray (10YR 7/2). Unit commonly forms large prominent, sharp-crested lateral moraines that are very bouldery and have distinct constructional morphology. Unit locally includes deposits of stratified drift, mass-movement deposits, till of Bull Lake age (Qtb), and locally may include till of pre-Bull Lake age. Radiocarbon $\left({ }^{14} \mathrm{C}\right)$ and cosmogenic surfaceexposure ages, some for deposits in nearby areas, indicate that till of unit Qtp is about 12-30 ka (Nelson and others, 1979; Madole, 1986; Schildgen and Dethier, 2000; Benson and others, 2004, 2005; 2007). Subsurface deposits and locally some surface deposits of unit Qtp may be older than $30 \mathrm{ka}$, because uranium-series ages of travertine in the northern Yellowstone area suggest an advance of Pinedale ice occurred about 34-47 ka (Sturchio and others, 1994). Estimated thickness is $1.5-30 \mathrm{~m}$

Till of Bull Lake age (late and middle Pleistocene) - Mostly non-sorted and non-stratified, subangular and subrounded boulders to granules in a slight silty to silty sand and, locally, in a clayey silt matrix. Clasts are commonly angular to subangular and make up about $40-80$ percent of the deposits. Boulders composed of granite, gneiss, and pegmatite commonly are 1-2 m long. Near Ranch Creek, about $3.5 \mathrm{~km}$ east of Fraser, deposits locally contain Proterozoic clasts as long as 2.5-9 m. Many of the biotite-rich pebbles and cobbles composed of granite, gneiss, and schist within the surface soil are weathered and are partly or completely disintegrated. Material less than $2 \mathrm{~mm}$ in diameter makes up about 20-60 percent of the deposits. Unit Qtb has a slightly silty to silty sand matrix in areas where it is derived from Proterozoic bedrock, but locally has a clayey silt matrix, such as at Winter Park, where it contains abundant sediment eroded chiefly from the Troublesome Formation (NPEt. Unit is oxidized (10YR 6/3 or 10YR7/3) to a depth of greater than 3.5 $\mathrm{m}$; unoxidized matrix is light gray (10YR 7/2). Unit commonly forms prominent lateral moraines that have rounded crests beyond the outer limit of till of Pinedale age (Qtp). Unit Qtb locally includes deposits of stratified drift, mass-movement deposits, and till of Pinedale age (Qtp). Much of unit Qtb along Ranch Creek lacks morainal form and locally may include till of pre-Bull Lake age on the east side of Ranch Creek, about $25-840 \mathrm{~m}$ south of Little Cabin Creek. K-Ar and ${ }^{230} \mathrm{Th} / \mathrm{U}$ analyses that constrain the ages of glaciofluvial deposits near the type area for the Bull Lake glaciation along the north flank of the Wind River Range, Wyo., and ages of glacial deposits near West Yellowstone indicate that the Bull Lake glaciation probably began prior to $167 \pm 6.4 \mathrm{ka}$ (possibly $190 \mathrm{ka}$ ) and may have continued until about $122 \pm 10 \mathrm{ka}$ (Sharp and others, 2003; Pierce, 2004). ${ }^{10} \mathrm{Be}$ and ${ }^{26} \mathrm{Al}$ analyses of surface boulders on moraines composed of till of Bull Lake age near Nederland, Colo., yielded minimum age estimates of $101 \pm 21$ and $122 \pm 26$ ka (Schildgen and others, 2002). These age estimates are in accordance with a uranium-trend age estimate of $130 \pm 40 \mathrm{ka}$ for till of Bull Lake age (Shroba and others, 1983) near Allens Park, Colo. Estimated thickness is 1.5-15 m 
Till of Pinedale age and till of Bull Lake age, undivided (late and middle Pleistocene) - Unit consists chiefly of till of Pinedale age (Qtp) and a minor amount of till of Bull Lake age (Qtb), along Ranch Creek and Cabin Creek, where till of Bull Lake age is of limited extent or is difficult to distinguish from till of Pinedale age. In some areas mapped as unit Qti, till of Bull Lake age may be mantled by till of Pinedale age and is not exposed. Unit Qti locally includes stratified drift and mass-movement deposits, and locally may include a minor amount of till of pre-Bull Lake age that lacks depositional morphology. Estimated thickness is $1.5-30 \mathrm{~m}$

\section{Bedrock Units}

\section{Post-Laramide Sedimentary and Volcanic Rocks}

Troublesome Formation (upper Miocene to upper Oligocene) - Poorly exposed outcrops and small manmade exposures of unit NPEt in the Fraser basin (figs. 2, 3) consists chiefly of weakly consolidated siltstone, minor interbedded sandstone and conglomerate, and locally unconsolidated sand and gravel. Lithologic data in driller's logs for water wells near Fraser and Tabernash suggest that the unit in the subsurface consists chiefly of siltstone (Bauch and Bails, 2003). Much of the Troublesome in the Troublesome basin in the Hot Sulphur Springs quadrangle, northwest of the Fraser quadrangle (fig. 2), is also composed of siltstone (Izett, 1968). Sandstone and conglomerate probably are more common near the depositional margins of the unit, particularly where main streams entered the Fraser basin. Siltstone probably is more common in the rest of the basin. Limited lithologic data in driller's logs suggest that sandstone and conglomerate locally form discontinuous channel-fill deposits of variable thickness (about $0.3-17 \mathrm{~m}$ ) within more uniform intervals of fine-grained sediment (probably mostly siltstone). Siltstone exposed in near-surface, man-made exposures consists of white (10YR 8/2) and pink (7.5YR 7/4), massive, slightly clayey silt and sandy silt. Some of the clay is altered volcanic ash (Zielinski, 1982). Near the northern margin of the Fraser basin, near the northwest corner of the map area, massive siltstone locally contains lenses of interstratified fluvial conglomeratic sandstone and pebble conglomerate in stream channels commonly about $5 \mathrm{~m}$ wide and $3 \mathrm{~m}$ thick. The conglomeratic sandstone consists of carbonate-cemented, poorly sorted, very fine to very coarse sand that contains abundant granitic granules and pebbles commonly about $0.5-3 \mathrm{~cm}$ in diameter. Conglomerate consists of thinly $(5-35 \mathrm{~cm})$ bedded, carbonate-cemented, granitic pebble gravel (commonly $0.4-2 \mathrm{~cm}$ in diameter) that locally contains lenses of granule-rich, mostly coarse to very coarse sand and scattered cobbles. Cobbles are angular to subangular granite, quartz, gneiss, and pegmatite commonly as long as $10-20 \mathrm{~cm}$. Siltstone near Maryvale, about $3 \mathrm{~km}$ southeast of Fraser, locally contains lenses of unconsolidated silty, very fine to fine sand and weakly consolidated sandstone. The siltstone locally contains lenses (about 3-200 cm thick) composed of unconsolidated (1) very fine to medium sand, (2) granule-rich, non-pebbly to pebbly, medium to very coarse sand, and (3) clast-supported, granitic gravel that range in size from small pebble $(\leq 2 \mathrm{~cm}$ in diameter) to slightly cobbly, coarse pebble gravel. Gravel lenses locally contain subangular and subrounded clasts of rhyolite tuff $\left(\mathrm{P}_{\mathrm{et}}\right)$ as large as $15 \mathrm{~cm}$ in diameter. Weathered siltstone at and near the ground surface commonly is strong brown ( $7.5 \mathrm{YR} 5 / 6)$, clayey to very clayey silt that is massive or has very coarse, blocky soil structure. Siltstone locally contains thin (perhaps $2-20 \mathrm{~cm}$ ) lenses of vitreous volcanic ash. Some of the ash in the unit has been altered to smectite (montmorillonite) clay (Zielinski, 1982). Probably all gradations exist between vitreous ash and ash that is completely altered to clay. Some of the lithologic logs of drill holes for water wells along the Fraser River near the town of Fraser suggest that the Troublesome near Fraser locally overlies shale, which may be Cretaceous marine shale (Benton Shale or Pierre Shale) exposed in the adjacent Bottle Pass quadrangle (Taylor, 1975). Interstratified sandstone and coarse pebble conglomerate of the Troublesome, penetrated in the lower part of these drill holes, probably are of fluvial origin. Cretaceous shale locally may underlie the Troublesome near the northwest corner of the Fraser quadrangle. The driller's $\log$ for a water well, located about $2 \mathrm{~km}$ west of the northwest corner of the Fraser quadrangle, suggests that about $22 \mathrm{~m}$ of Troublesome overlies about $23 \mathrm{~m}$ of shale, which in turn overlies Proterozoic rock, probably granodiorite (Taylor, 1975). Unit NPEt in the Fraser quadrangle has measured dips of 5-16 ${ }^{\circ}$, is slightly tilted (Tweto, 1957), and is locally faulted. Siltstone in areas with steep slopes is prone to displacement by creep, sliding, and other mass-movement processes. Original thickness unknown, because top is everywhere eroded. Thickness based on outcrop and drill-hole data is at least $150 \mathrm{~m}$ near Fraser and about $255 \mathrm{~m}$ near Tabernash; probably is locally greater than $245 \mathrm{~m}$ thick in the adjacent Bottle Pass quadrangle (Taylor, 1975); and is as much as $300 \mathrm{~m}$ or more in the nearby Granby quadrangle (Schroeder, 1995b) 
$P_{\varepsilon t}$

Rhyolite tuff (Oligocene) - Weakly welded, white, rhyolitic, crystal-lithic tuff and tuff breccia that underlies the Troublesome Formation (NPt) near the southern margin of the Fraser basin (Taylor and others, 1968). The largest exposure of the tuff, just east of Winter Park, contains conspicuous sanidine, plagioclase, and clear to smoky bipyramidal quartz phenocrysts in a white matrix of variably devitrified glass. Pumice fragments make up about 25 percent of the rock (Taylor and others, 1968). The tuff contains gas cavities commonly as large as $3 \mathrm{~cm}$ in diameter. Sanidine from welded tuff, about $0.5 \mathrm{~km}$ east of Winter Park, yielded an ${ }^{40} \mathrm{Ar} /{ }^{39} \mathrm{Ar}$ age of 27.3 $\pm 0.1 \mathrm{Ma}$ (Knox, 2005; corrected by E.E. Larson, U. of Colo., Boulder, written commun., 2009, based on new analytical standards). Talus deposits (Qta) locally form near the base of large outcrops of rhyolite tuff. Weathered rhyolite commonly consists of angular to subangular, blocky to tabular clasts about 2-100 cm long; voids between clasts contain a matrix of pinkish white $(7.5 \mathrm{YR} 8 / 2)$ slightly silty, very fine to very coarse rhyolite sand. Contacts of unit $P_{\varepsilon t}$ with other rock units are not exposed. Estimated thickness is 15 to greater than $150 \mathrm{~m}$

\section{Pre-Laramide Sedimentary Rocks}

Dakota Group (Lower Cretaceous) - Unit consists chiefly of light-gray to tan, thin- to massive-bedded, finegrained sandstone and conglomeratic sandstone that formed during transgression of the Cretaceous Interior Seaway (Taylor, 1975); exposed only near the southwest corner of the Fraser quadrangle. Sandstone locally grades into orthoquartzite; cross bedding is common (Tweto, 1957). Sandstone in the upper part of the unit $(\mathrm{Kd})$ contains a minor amount of carbonaceous siltstone and shale. Conglomeratic sandstone and chertpebble conglomerate are present near the base of the unit (Taylor, 1975). Near the southern margin of Middle Park Formation the Dakota disconformably overlies the Morrison Formation (Tweto, 1957). Thickness in the adjacent Bottle Pass quadrangle is about $75 \mathrm{~m}$ (Taylor, 1975)

Morrison Formation (Upper Jurassic) - Unit consists chiefly of poorly exposed, mostly fluvial, light brownish-gray, greenish-gray, and grayish-red silty claystone and mudstone that contain interbedded fine-grained sandstone, south of the east-west-trending fault, near the southwest corner of the Fraser quadrangle. In the adjacent Bottle Pass quadrangle, unit $\mathrm{Jm}$ locally contains thin, discontinuous lenses of fine-grained limestone (Taylor, 1975). The Morrison is the basal Phanerozoic unit in this area. It overlies Proterozoic basement, and is disconformably overlain by rocks of the Dakota Group near the southern margin of Middle Park (Tweto, 1957). Thickness in the adjacent Bottle Pass quadrangle is about 45-75 m (Taylor, 1975)

\section{Proterozoic Rocks}

Yp

$\mathrm{Ym}$

YXp

YXg

Pegmatite of the Berthoud Plutonic Suite (Mesoproterozoic) - Muscovite-microcline-albite-quartz pegmatite, alaskite, and aplite. Contains scattered inclusions of country rock. Unit extends into the Fraser quadrangle from the south where it forms part of the northern margin of the Silver Plume batholith (Theobald, 1965)

Monzogranite and granite of the Berthoud Plutonic Suite (Mesoproterozoic) - Seriate-porphyritic biotite monzogranite and granite that show a prominent flow alignment of tabular microcline crystals (Silver Plumetype granite; Tweto, 1987); locally contains unoriented flakes of subsolidus muscovite. Includes small bodies of muscovite-microcline-albite-quartz pegmatite. Unit consists of two small rock bodies (one near the southeast corner of the quadrangle and one near East Elk Creek at the south boundary of the quadrangle) near the northern margin of the Silver Plume batholith (Theobald, 1965)

Pegmatite (Mesoproterozoic or Paleoproterozoic) - Muscovite- or biotite-bearing pegmatite, aplite, and alaskite. Mapped outside the swarm of pegmatites (Yp) north of the Silver Plume batholith, near the southeast corner of the Fraser quadrangle

Granodiorite and monzogranite (Mesoproterozoic or Paleoproterozoic) - Biotite granodiorite and monzogranite that are medium to coarse grained and massive to foliated. Unit consists of small rock bodies mapped east of the Fraser River in the southeastern part of the quadrangle. Probably equivalent in part to Paleoproterozoic granitic rocks (Xgd; Routt Plutonic Suite of Tweto, 1987), but designated with equivocal age because some similar-appearing rocks in the region have produced Mesoproterozoic ages (Berthoud Plutonic Suite of Tweto, 1987; Kellogg and other, 2008) 
Xgd Foliated granodiorite, tonalite, and diorite of the Routt Plutonic Suite (Paleoproterozoic) - Medium grained, dark gray, variably foliated plutonic rocks containing biotite or biotite and hornblende. Grain size generally 2-5 mm. Finer grained in more strongly foliated zones. A preliminary SHRIMP U-Pb zircon age of 1,718.9 \pm 8.5 Ma was determined from a sample collected in a roadcut along U.S. Highway 40, just north of Winter Park Ski Area (W.R. Premo, U.S. Geological Survey (USGS), Denver, Colo., written commun., 2008). These rocks are similar to widespread foliated granodiorite and related rocks of Paleoproterozoic age (Routt Plutonic Suite of Tweto, 1987)

Xmg Migmatitic biotite schist and gneiss (Paleoproterozoic) —Biotite, sillimanite-biotite, garnet-biotite, and garnetsillimanite-biotite schist and gneiss that display irregular layers and lenses of variable granitic composition (leucosomes) bordered by darker layers (melanosomes) rich in biotite, sillimanite, and magnetite. Leucosomes commonly are $1-5 \mathrm{~cm}$ thick, but are locally as much as $5 \mathrm{~m}$ thick. They are interpreted to have formed as partial melts from adjacent rocks (Olsen, 1982). Garnet is pale-pink and typically $5 \mathrm{~mm}$ or less in diameter; sillimanite needles are as much as $1 \mathrm{~cm}$ long and locally form bundles as long as $2 \mathrm{~cm}$. Some areas of unit Xmg in the Fraser quadrangle were incorrectly labeled "Porphyroblastic quartz-biotite-muscovite schist of White Ranch (Xbp)" in the Denver West quadrangle compilation (Kellogg and others, 2008)

Xhc

Hornblende gneiss and calc-silicate gneiss (Paleoproterozoic) - Hornblende gneiss, amphibolite, calc-silicate gneiss, and a few layers of marble. Calc-silicate rocks contain various proportions of epidote, diopside, amphibole, plagioclase, and quartz. Adjoining areas to the south in the Berthoud Pass quadrangle were mapped as "hornblende gneiss" without conspicuous calc-silicate rocks (Theobald, 1965)

Xig Interlayered gneiss (Paleoproterozoic) - Biotite schist and gneiss, quartzofeldspathic gneiss, quartz-rich gneiss, calc-silicate gneiss, biotite marble, and pegmatite. Layers are mostly 1-10 cm thick. Mapped along the northern border of the quadrangle, contiguous with heterogeneous interlayered gneisses in the adjacent Strawberry Lake quadrangle (Schroeder, 1995b) that are contained within a more extensive terrane of migmatitic biotite schist and gneiss $(\mathrm{Xmg})$

Table 2. Approximate height, in meters, of top of gravelly stream alluvium $(\mathrm{Og}$ and $\mathrm{ONg}$ ) above the Fraser River and its major tributaries Saint Louis Creek and Ranch Creek in the Fraser 7.5-minute quadrangle.

[..., no deposits along stream]

\begin{tabular}{lccccc}
\hline Map unit & \multirow{2}{*}{$\begin{array}{c}\text { near } \\
\text { Winter Park }\end{array}$} & $\begin{array}{c}\text { Fraser } \\
\text { River } \\
\text { near } \\
\text { Fraser }\end{array}$ & $\begin{array}{c}\text { near } \\
\text { Tabernash }\end{array}$ & $\begin{array}{c}\text { Saint Louis } \\
\text { Creek } \\
\text { near } \\
\text { Fraser }\end{array}$ & $\begin{array}{c}\text { Ranch } \\
\text { Creek } \\
\text { northeast of } \\
\text { Fraser }\end{array}$ \\
\hline $\mathrm{Qg}_{1}$ & 6 and 12 & 6 and 12 & 6 & 6 & $6-9$ \\
$\mathrm{Qg}_{2}$ & 24 & 24 & 12 and 18 & 12 & $18-24$ \\
$\mathrm{Qg}_{3}$ & $\ldots$ & 30 & 35 & $\ldots$ & $30-35$ \\
$\mathrm{Qg}_{4}$ & $\ldots$ & $50-55$ & $\ldots$ & $\ldots$ & $50-55$ \\
$\mathrm{Qg}_{5}$ & $\ldots$ & $\ldots$ & 65 & $\ldots$ & 65 \\
$\mathrm{Qg}_{6}$ & $\ldots$ & $85-90$ & $\ldots$ & $\ldots$ & $\ldots$ \\
$\mathrm{Qg}_{7}$ & $\ldots$ & $105-115$ & $\ldots$ & $\ldots$ & $\ldots$ \\
$\mathrm{Qg}_{8}$ & 145 & $\ldots$ & $\ldots$ & $\ldots$ & $\ldots$ \\
$\mathrm{QNg}$ & $245-270$ & $\ldots$ & $\ldots$ & $\ldots$ & $\ldots$ \\
\hline
\end{tabular}




\section{Eolian Silt Contributions to the Troublesome Formation in the Fraser Basin}

Sparse and widely separated outcrops, excavations, and water wells that have driller's logs in the Fraser basin suggest that much of the upper $150 \mathrm{~m}$ of the Troublesome Formation $\left(N P_{\varepsilon} t\right)$ near Fraser and about $255 \mathrm{~m}$ of Troublesome Formation near Tabernash consists chiefly of siltstone. This observation is puzzling, because the Troublesome Formation was deposited in an intermontane basin (Izett, 1968), and many of basin-margin rocks are Proterozoic crystalline rocks that only produce a minor amount of silt upon weathering.

In natural and man-made exposures in the Fraser basin, siltstone is massive and locally contains lenses and channelfill deposits composed of sandstone and conglomerate, and unconsolidated sand and gravel. The siltstone lacks distinctive lacustrine features (Feth, 1964; Picard and High, 1981), as well as diagenetic minerals and features commonly associated with saline playa deposits (Zielinski, 1982; Chapin and Lindley, 1986). The lack of distinctive lacustrine features may be due to deposition in shallow ephemeral lakes in which wave action or bioturbation destroyed or obscured primary sedimentary features. Although the Troublesome Formation in the Troublesome basin (fig. 2) contains a few beds of fresh-water limestone, it contains an exclusively terrestrial fauna and lacks fossil fish (Izett, 1968 and references within; Kron, 1988).

Most of the sand-size and coarser sediments, and probably much of the silt-size sediments that make up the Troublesome Formation, were eroded from basin margins and deposited in adjacent basins by alluvial processes (Tweto, 1957; Izett, 1968). The silt that makes up the abundant siltstone in the Fraser basin, as well as in the Troublesome and Granby basins, may be derived chiefly from either the deposition of (1) volcanic ash (primary airfall) and ash-rich alluvium, or (2) loess (windblown silt) and loess-rich alluvium.

It is unlikely that much of the substantial silt that accumulated in the Fraser basin was derived from the weathering and erosion of crystalline and sedimentary bedrock along the margins of the basin. The Proterozoic granitic rocks, schist, and gneiss are unlikely sources because they weather to form coarse-grained deposits, such as sandy matrix colluvium (Qcs). The latter contains abundant clasts, substantial amounts of very coarse sand to medium sand rich in quartz and feldspar, and only minor amounts of silt and clay. Marine deposits of the Benton Formation, Niobrara Shale, and Pierre Shale, and continental deposits of the Middle Park Formation along the western margin of the basin in the adjoining Bottle Pass quadrangle contain varying amounts of claystone, siltstone, shale, and mudstone (Taylor, 1975). However, it is unlikely that sediments derived from these bedrock units alone could account for the high proportion of siltstone in the Troublesome Formation of the Fraser basin, because they are so limited (in volume) here.
Some of the silt in the lower part of the Troublesome Formation in the Fraser basin could be derived from Oligocene ash or eolian sediment that once blanketed the landscape and later was redeposited as silt-rich alluvium. For example, the thick remnant of crystal-rich lithic tuff near Winter Park beneath the Troublesome Formation indicates a nearby volcanic source at Red Mountain (fig 1; Shannon and others, 2004. Other possible sources include volcanic vents in the Rabbit Ears Range (Izett, 1968), the Never Summer Mountains (fig. 2; Cole and others, 2008), and an inferred buried source in the Fraser quadrangle (Tweto, 1957; Taylor and others, 1968; Stein and Crock, 1990). Some of the very fine silt and clay in the siltstone could be (1) distal ash erupted from major volcanic fields nearby or in the Basin and Range province (Hansen, 1984; Luft, 1985; Buffler, 2003) hundreds of kilometers west of the Fraser basin, or (2) dust deflated from the extensive Chuska erg (Cather and others, 2008) about $400 \mathrm{~km}$ southwest of the Fraser basin.

Massive bedding and limited grain-size data suggest that a major component of the siltstone in the Troublesome Formation of the Fraser basin is loess that is the distal facies of extensive deposits of eolian sand (Pye, 1987, 1995), or siltrich alluvium derived from loess deposits. The Troublesome Formation is coeval with extensive eolian sand sheets and loess deposits that accumulated in areas northwest, northeast, and south of the Fraser basin. On the west side of the Park Range, about $45 \mathrm{~km}$ northwest of Fraser basin (north of Gore Range; fig. 2), as much as $670 \mathrm{~m}$ of mostly very fine-to medium-grained, cross-bedded eolian sandstone in the Browns Park Formation accumulated between about 24.8 and 7.2 Ma (Luft, 1985; Buffler, 2003 ). Tuffs within the Browns Park thin from west to east suggesting transport by westerly or southwesterly winds (Luft, 1985; Buffler, 2003). On the high plains of eastern Wyoming and southwestern Nebraska, about 200 $\mathrm{km}$ northeast of the Fraser basin, the uppermost lithostratigraphic unit of the "Upper Harrison" beds of Peterson (1907, 1909) of latest Arikareean age (Tedford and others, 2004 ) consists of as much as $35 \mathrm{~m}$ of silty very fine to fine eolian sandstone (sandy loess) that accumulated during the early Miocene, probably under warm semiarid climatic conditions (Hunt, 1990) on a landscape dominated by $\mathrm{C}_{3}$-grassland vegetation (Strömberg, 2002). In the Rio Grande rift of northcentral New Mexico, about $500 \mathrm{~km}$ south of the Fraser basin, about $350 \mathrm{~m}$ of mostly cross-bedded eolian Zia Sand was transported by westerly winds and accumulated between about 22 and $16 \mathrm{Ma}$ (Tedford and Barghoorn, 1999; Williams and Cole, 2007).

Limited grain-size data for samples of clayey siltstone, siltstone, and silty sandstone collected from the Troublesome Formation near the town of Fraser indicate that most of the particles are 1-125, 16-250, and 31-500 $\mathrm{mm}$ in size for the three samples, respectively (table 1). By comparison, unweathered loess of Quaternary age is composed mainly of particles 10-50 mm in size (Pye, 1987, 1995). Values for mean particle size and degree of sorting for the samples of clayey siltstone and siltstone (1) are similar to those of airborne dust in the 


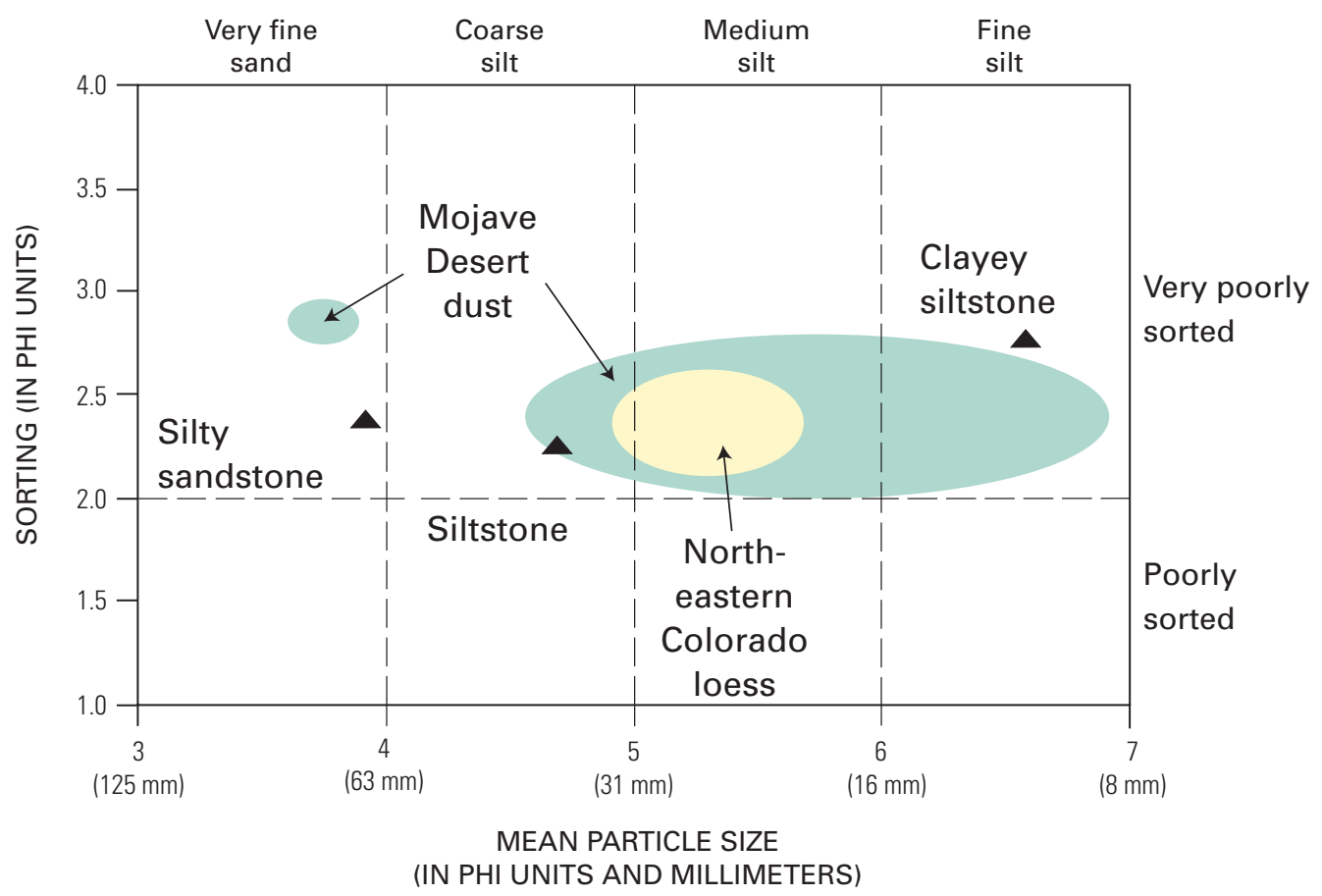

Figure 4. Plot of mean particle size and degree of sorting (standard deviation of the mean particle size) of silty sandstone, siltstone, and clayey siltstone collected from the Troublesome Formation near Fraser, Colorado (triangles). Data for modern airborne dust in the Mojave Desert in southern California (green), and late Pleistocene and early Holocene loess in northeastern Colorado (yellow) are from Muhs and Benedict (2006, their fig. 5).

Mojave Desert and (2) suggest that these siltstones formed from loess or loess-rich alluvium (fig. 4). The relatively high clay content of the clayey siltstone, which is uncommon in modern dust, may be due in part to post-depositional, diagenetic alteration of volcanic ash to secondary clay-size clay minerals (Zielinski, 1982).

The deposition of eolian sediment in the Troublesome Formation and extensive coeval regional eolian units suggests that semiarid climatic conditions prevailed regionally during the late Oligocene and Miocene. However, limited pollen data suggest that climatic conditions during the deposition of the Troublesome Formation (about 28.4-11 Ma) may not have been much drier than those of the present (table 3 ). The pollen assemblages in two samples of fine-grained carbonaceous sediment from the Troublesome Formation, collected about 11 and $13 \mathrm{~km}$ northeast of Kremmling, Colo. (U.S. Geological Survey Botanical localities D1905 and D3493, respectively; stratigraphic positions not specified), are dominated by pine (D3493) and by pine and subordinate spruce (D1905) (E.B. Leopold, USGS, Denver, Colo., written commun., 1962 and 1964). Except for the presence of scarce pollen from broadleaf trees (Ulmus (elm), Carya (hickory), and Juglans (walnut)), now exotic in Colorado, these fossil pollen assemblages resemble the present pollen rain in the area (E.B. Leopold, unpublished data; cited by Weber, 1965). The present natural geographic ranges of these broadleaf trees are limited to areas of the United States that have a mean annual precipitation of at least 35-55 cm (Thompson and others, 1999), which is greater than that of the Kremmling area (table 3 ).

Table 3. Mean annual precipitation near Kremmling, Granby, and Fraser, Colo.

\begin{tabular}{lcc}
\hline $\begin{array}{l}\text { Weather } \\
\text { station name }\end{array}$ & $\begin{array}{c}\text { Approximate } \\
\text { elevation }(\mathbf{m})\end{array}$ & $\begin{array}{c}\text { Mean annual } \\
\text { precipitation } \mathbf{( c m})\end{array}$ \\
\hline Kremmling $^{1}$ & 2,250 & 29 \\
Granby $^{2}$ & 2,500 & 36 \\
Fraser $^{1}$ & 2,610 & 47 \\
\hline
\end{tabular}

${ }^{1}$ Values for Kremmling (1908-2009) and Fraser (1908-1974) are from http://www.wrcc.dri.edu.

${ }^{2}$ Value for Granby (1959-1974) is from Hansen and others (1978). 


\section{Structural Setting of the Fraser 7.5-minute Quadrangle}

The Fraser 7.5-minute quadrangle is located along the western boundary of the Laramide Front Range basement uplift (Tweto, 1957), near the southeastern margin of a physiographic feature known as Middle Park (fig. 2). Middle Park and North Park (North Park is north of Rabbit Ears Range, see fig. 2) lie within an intermontane basin that formed between the Laramide Medicine Bow Mountains (north of Never Summer Mountains; fig. 2) and Front Range on the east and the Park and Gore Ranges on the west (Tweto, 1980). The basin is filled mostly with Upper Cretaceous(?) to Paleocene sedimentary and volcanic rocks, which are cut by a complex array of both thrust and normal faults in the Bottle Pass quadrangle, immediately west of the Fraser quadrangle. The fault geometry is complex, and is chiefly the result of southwest-directed Laramide thrusting (Taylor, 1975).

Three north- to northwest-trending, post-Laramide basins formed near the eastern and western margins of the Laramide North Park-Middle Park structural basin. The upper Oligocene to upper Miocene Troublesome Formation occupies the central parts of the Troublesome, Granby, and Fraser basins and, locally, unconformably overlies Proterozoic to Paleocene rocks (fig. 2). These basins consist of paleovalleys and structural lows (Izett, 1975); the latter probably formed during extensional deformation associated with the Rio Grande rift system in northern Colorado (Tweto, 1978, 1979b; Chapin and Cather, 1994). The Fraser quadrangle encompasses much of the Fraser basin, which contains sediments of the Troublesome Formation (NPt).

Two major faults are inferred to traverse parts of the quadrangle based on geologic relations in adjacent areas (Kellogg and others, 2008). The northeast-trending Vasquez Pass fault is inferred beneath the Vasquez Creek valley, but there is no evidence it displaces the Troublesome Formation. A northtrending branch of the generally northeast-trending Berthoud Pass fault zone (a complex array of brittle faults and fractures that disrupts some older mylonite) passes through the extreme southeast corner of the Fraser quadrangle. A minor fault with youngest known displacement in the quadrangle is the short northwest-trending structure near Maryvale, about $1 \mathrm{~km}$ north of Winter Park, which displaces beds of the Troublesome Formation.

The Saint Louis Lake shear zone is one of a series of zones of ductile deformation formed during the Proterozoic (Tweto and Sims, 1963; Taylor, 1971; Shaw and others, 2002). It is part of a major northeast-trending zone in central Colorado referred to collectively as the Homestake shear zone (Tweto and Sims, 1963). Where best exposed, at Saint Louis Lake in the Byers Peak quadrangle $8.5 \mathrm{~km}$ southwest of the Fraser quadrangle, ductilely deformed rocks in the Saint Louis Lake shear zone contain monazite grains that are interpreted to indicate medium-temperature recrystallization in mylonites at about 1.4 Ga (McCoy and others, 2005).

\section{Geologic History of the Fraser 7.5-minute Quadrangle}

The geologic history of the quadrangle can be divided into three major periods: (1) Proterozoic history, (2) Paleozoic through Laramide history (Late Cretaceous to early Eocene), and (3) post-Laramide Cenozoic history. Some of the geologic history below is summarized from Kellogg and others (2008).

\section{Proterozoic History}

The history of the basement rocks in the Fraser quadrangle may extend as far back as about 1,800 Ma (Reed and others, 1987; Aleinikoff and others, 1993). The oldest metasedimentary rocks formed chiefly from marine shale and siltstone (Cole and Braddock, 2009), sparse mafic volcanic flows and tuffs, and a few thin beds of limestone. None of the layered metamorphic rocks in or near the Fraser quadrangle have been dated. SHRIMP (Sensitive high-resolution ion microprobe) analyses of zircon in similar rocks, about $50 \mathrm{~km}$ southeast of the Fraser quadrangle, indicate that at least some of the metamorphosed volcanic rocks are as old as 1,770-1,780 Ma (Premo and others, 2007). Some of the metavolcanic rocks dated by Premo and Van Schmus (1989) in the Sierra Madre of southern Wyoming are of similar age.

The marine sediments were folded and metamorphosed concurrent with or after intrusion by granodiorite plutons (Xgd). Evidence for this is the concordance of pluton contacts and foliation in the plutonic rocks with the layering and foliation of the adjacent metasedimentary rocks. Rock of the main granodiorite pluton, collected in a roadcut along U.S. Highway 40 just north of Winter Park Ski Area, has a preliminary SHRIMP U-Pb zircon age of 1,718.9 $\pm 8.5 \mathrm{Ma}$ (W.R. Premo, USGS, written commun., 2008). Eppinger and others (1985) reported that small bodies of plutonic rock, correlative with the larger, dated pluton in the Fraser quadrangle are folded.

Foliation and compositional layering in the Proterozoic rocks are generally parallel, except in rare outcrops exposing a fold hinge, where foliation penetrates compositional layering. Trends of foliation and compositional layering are generally east to east-northeast. In the southern part of the Fraser quadrangle, the Proterozoic rocks have a more consistent foliation trend and dip than elsewhere. Lineation formed by aligned minerals, stretched-mineral trains, and rodding have a consistent southeast trend.

Strands of the Saint Louis Lake shear zone cut Proterozoic rocks in the southern part of the Fraser quadrangle. At Saint Louis Lake in the Byers Peak quadrangle, mylonite along the shear zone is interpreted to have formed at temperatures of $350-450^{\circ} \mathrm{C}$ at $1.42 \mathrm{Ga}$, and thin zones of ultramylonite contain monazite dated at $1.34 \mathrm{Ga}$ (McCoy and others, 2005). 


\section{Paleozoic through Laramide History}

Lower Paleozoic sedimentary rocks probably were deposited in the Fraser area but were removed during Pennsylvanian and later time when the Ancestral Front Range was uplifted (DeVoto, 1980). In the Fraser quadrangle and the Bottle Pass quadrangle to the west, the Upper Jurassic Morrison Formation $(\mathrm{Jm})$ was deposited directly on the Proterozoic basement rocks following uplift and prolonged erosion (Taylor, 1975). Nearby, to the north, in the Strawberry Lake and Granby quadrangles sedimentary rocks overlying the basement belong to the Triassic Chugwater Formation (Schroeder, 1995a, 1995b).

During Late Cretaceous the area was beneath a shallow, inland sea in which more than $2 \mathrm{~km}$ of Upper Cretaceous Pierre Shale was deposited (Izett, 1968). Near the end of the Cretaceous, uplift and erosion related to the Laramide orogeny began (Tweto, 1957, 1975, 1980). This deformation established the outlines of the main basement uplifts of the Front Range and Vasquez Mountains (fig. 2). West of the Fraser quadrangle, Laramide-age reverse faults deformed rocks as young as the Paleocene and Upper Cretaceous(?) Middle Park Formation.

Locally, on the west side of the Front Range, much of the Pierre Shale was eroded before mafic volcanic conglomerate in the lower part of the Middle Park Formation was deposited (Tweto, 1957). The Middle Park Formation consists of volcaniclastic and arkosic sandstone and conglomerate that are about $2.2 \mathrm{~km}$ thick in the Hot Sulphur Spring 15-minute quadrangle (Izett, 1968) northwest of the Fraser quadrangle. It was faulted and folded, probably during the late Paleocene or early Eocene (Tweto, 1957, 1975, 1980).

Apatite fission-track cooling ages of 67-48 Ma along Clear Creek Canyon, about $35 \mathrm{~km}$ southeast of the Fraser quadrangle, suggest Laramide denudation in the eastern part of the Front Range during latest Cretaceous to middle Eocene time (Chapin and Kelley, 1997).

\section{Post-Laramide Cenozoic History}

After a period of erosion during the Eocene and early Oligocene time, three northwest- to north-trending basins were formed by tectonic processes that probably were similar in character and age to those in the Rio Grande rift in central and southern Colorado (Tweto, 1978, 1979b; Kellogg, 1998). These basins contain rocks and locally weakly consolidated sediments assigned to the upper Oligocene to upper Miocene Troublesome Formation (NPt). The Troublesome Formation probably was deposited in one irregular basin that is now separated into three basins by later erosion and some normal faulting (Izett, 1968). The western basin is the Troublesome basin (Tweto, 1957; Izett, 1968; Izett and Barclay, 1973). Sediments in the two eastern basins are preserved in the relatively low-lying land surrounding Granby and Fraser (Taylor and others, 1968). The boundary between the Granby and Fraser basins is near the north-trending ridge of Proterozoic bedrock
(Tweto, 1957), where the locally exposed Troublesome Formation is narrowest (fig. 2). The boundary does not appear to be structurally controlled, but rather is located where thin Troublesome Formation onlaps a low topographic divide in the underlying basement rocks (see Schroeder, 1995a).

The eroded top of the Troublesome Formation in the Fraser basin ranges in altitude from about 2,990 m near the eastern boundary of the Fraser quadrangle, southeast of the town of Winter Park, to about 2,715 m near the northern boundary of the Bottle Pass quadrangle (Taylor, 1975) west of Tabernash. Sparse remnants of Troublesome are preserved on top of Proterozoic basement at about 2,800 $\mathrm{m}$ in the Strawberry Lake quadrangle to the north (Schroeder, 1995a). Widely spaced outcrops, excavations, and water wells with driller's logs near Tabernash indicate that the northern part of the Fraser basin contains about $255 \mathrm{~m}$ of Troublesome Formation not removed by post-Troublesome erosion (fig. 2).

Weakly welded porphyritic rhyolite tuff $\left(\mathrm{P}_{\varepsilon} \mathrm{t}\right)$, with an ${ }^{40} \mathrm{Ar} /{ }^{39} \mathrm{Ar}$ sanidine age of $27.3 \pm 0.1 \mathrm{Ma}$ (Knox, 2005; corrected by E.E. Larson, U. of Colo., Boulder, written commun., 2009, based on new analytical standards) underlies the Troublesome Formation in the southern part of the Fraser basin (Taylor and others, 1968), about $0.5 \mathrm{~km}$ east of Winter Park. The tuff has not been identified north of this locality in the Fraser quadrangle or anywhere in the Granby basin in the Granby and Trail Mountain quadrangles (Schroeder, 1995b; Izett, 1974). Contacts of the tuff with younger and older bedrock units are not exposed. Map relations indicate that, at least locally, the tuff overlies Proterozoic basement rocks. In other places the tuff is topographically higher than adjacent deposits of the Troublesome Formation, which locally contains clasts of similar rhyolite tuff in gravel lenses. These relationships indicate that the tuff is older than the Troublesome Formation, and that erosional remnants of the tuff may have locally formed hills around which, and probably over which, the Troublesome Formation was deposited.

The rhyolite tuff near Winter Park may have erupted from either (1) an eroded volcanic complex associated with the Red Mountain intrusive system, about $15 \mathrm{~km}$ south of the Fraser quadrangle (fig. 1; Stein and Crock, 1990); (2) a local source now concealed by the Troublesome Formation or Quaternary deposits (Tweto, 1957; Taylor and others, 1968; Stein and Crock, 1990); or (3) the Braddock Peak intrusive-volcanic complex (Cole and Braddock, 2009) in the Never Summer Mountains about $60 \mathrm{~km}$ north of Winter Park. The latter possibility was suggested by Kellogg and others (2008).

The rhyolite intrusive rocks of the Red Mountain magmatic system beneath Red Mountain (fig. 1) yield ${ }^{40} \mathrm{Ar} /{ }^{39} \mathrm{Ar}$ ages in the range $29.9 \pm 0.3 \mathrm{Ma}$ to $27.0 \pm 0.3$ (Geissman and others, 1992) that overlap the age of the rhyolite tuff near Winter Park (although the Red Mountain pluton most similar to the rhyolite tuff near Winter Park yielded an older age). Studies indicate that the plutons at Red Mountain were emplaced at a depth of about $1.6 \mathrm{~km}$ (Geraghty and others, 1988); magma associated with the intrusive system may have vented (Taylor and others, 1968). By 27.6 Ma, the intrusions 
in the core of the system were about $1.4 \mathrm{~km}$ below the present top of Red Mountain, and they had cooled below $280^{\circ} \mathrm{C}$ based on ${ }^{40} \mathrm{Ar} /{ }^{39} \mathrm{Ar}$ dating of biotite (Geissman and others, 1992).

These age data alone are inconclusive about a correlation of rhyolite intrusive rocks at Red Mountain to the rhyolite tuff near Winter Park (analytical procedures of the two investigations have not been directly compared). However, the rare-earth patterns of the tuff near Winter Park and the older rhyolite intrusions at Red Mountain are almost identical, suggesting a common magma source (Stein and Crock, 1990). In addition, the considerable thickness, high crystal content, and texture of the tuff near Winter Park indicate that it was erupted from a source not far away.

${ }^{40} \mathrm{Ar} /{ }^{39} \mathrm{Ar}$ ages for volcanic rocks of the Braddock Peak intrusive-volcanic complex (53 km north of the map area) indicate activity from about $29.2 \pm 0.2$ to $28.0 \pm 0.1 \mathrm{Ma}$ (Knox, 2005; corrected by E.E. Larson, U. of Colo., Boulder, written commun., 2009, based on new analytical standards). Rareearth patterns of the rhyolite tuff of Thunder Mountain (Cole and others, 2008) of the Braddock Peak intrusive-volcanic complex (Cole and Braddock, 2009) differ considerably from both those of the rhyolite tuff near Winter Park and the rhyolite at Red Mountain (Stein and Crock, 1990; Knox, 2005). Thus, age and geochemical data, as well as the considerable distances involved (greater than $60 \mathrm{~km}$ ), indicate that the Braddock Peak complex is an unlikely source for the tuff near Winter Park (E.E. Larson, U. of Colo., Boulder, written commun., 2009).

We favor the interpretation that the rhyolite tuff near Winter Park was erupted from either the Red Mountain area (Stein and Crock, 1990) or a concealed local source (Tweto, 1957; Taylor and others, 1968; Stein and Crock, 1990).

The range in altitude $(2,672-2,977 \mathrm{~m})$ at which the rhyolite tuff crops out near Winter Park suggests that either the tuff partly fills paleovalleys, similar in depth to the present valleys of the Fraser River and its tributary, Elk Creek, or it was displaced by subsequent faulting. There is no evidence that major faults displace the Troublesome Formation in the Fraser quadrangle however, deep pre-Miocene paleovalleys have been documented elsewhere in the northern Front Range and other nearby mountain ranges (Evanoff, 1990; Cole and others, 2008; Cole and Braddock, 2009). Topographic and geologic relations suggest that (1) the tuff near Winter Park occupies paleovalleys, and (2) there was significant topographic relief prior to the deposition of the Troublesome Formation. The latter interpretation is in accord with previous studies in the Troublesome basin near Kremmling and in the Granby basin north of Granby that indicate that the Troublesome unconformably overlies a surface of considerable relief (Izett, 1968, 1974; Braddock and Cole, 1990).

In the Trail Mountain quadrangle at the north end of the Granby basin, several basalt flows are interbedded with sediments in the lower part of the Troublesome Formation (Izett, 1974) and pinch out southward toward Granby (Schroeder, 1995b). The second lowest basalt flow has a corrected wholerock K-Ar age (using decay constants of Steiger and Jäger,
1977) of 26.7 $\pm 0.9 \mathrm{Ma}$ (Izett, 1974; Marvin and others, 1974). At the north end of the Granby basin a latite porphyry intrusion, with a zircon fission-track age of $28.4 \pm 2.3 \mathrm{Ma}$, probably intrudes Troublesome Formation beds beneath the lowest basalt (Izett, 1974), and locally is unconformably overlain by beds of the middle part of the Troublesome Formation (Braddock and Cole, 1990). These results indicate that the lower part of the Troublesome Formation in the north part of the Granby basin is Oligocene in age. South of the town of Granby, the Troublesome Formation contains vertebrate fossils of late Oligocene age (Kron, 1988; Schroeder, 1995b). The Troublesome Formation is very poorly exposed in the Fraser quadrangle, and the only isotopic-age control for the Troublesome Formation in this area is the 27.3-Ma rhyolite tuff that underlies it near Winter Park. In contrast, the Troublesome Formation is better exposed in the basin near Kremmling (Izett and Barclay, 1973) where it contains 30 or more tuffs and diagnostic vertebrate fossils that range in age from latest Arikareean to early Clarendonian (Izett and Obradovich, 2001). Eight of these tuffs have ${ }^{40} \mathrm{Ar} /{ }^{39} \mathrm{Ar}$ sanidine ages that range from 23.5 Ma to 11.0 Ma (latest Oligocene to late Miocene; Izett and Obradovich, 2001).

Locally, the Troublesome Formation is broadly folded and faulted. In the northern part of the Granby basin in the Trail Mountain quadrangle, the Troublesome Formation is folded into a broad, asymmetric syncline with dips as much as $29^{\circ}$ on the west limb and $20^{\circ}$ on the east limb (Izett, 1974). The syncline is cut by normal faults of small displacement (Izett, 1974). In the Granby quadrangle dips in the west part of the basin are as much as $27^{\circ}$, although most are less than $20^{\circ}$. Cross-sections for the Granby quadrangle (Schroeder, 1995b) show an interpreted fault with an implied $650 \mathrm{~m}$ displacement of the basal Troublesome Formation; surface and drillhole data do not seem to require a fault of such magnitude. The Troublesome Formation in that part of the Granby basin was deposited on a faulted, hilly terrane (Izett, 1968).

In the Fraser quadrangle, structures and bedding attitudes in the Troublesome Formation are poorly constrained, because much of the unit is very poorly exposed and is commonly mantled by colluvium and other surficial deposits. Poor exposure is also due, in part, to dense forest cover above an altitude of about 2,600 $\mathrm{m}$. The few measured dips and one observed normal fault that cuts the Troublesome Formation suggest that Troublesome beds are deformed, but not as much as those in the Granby basin. The fault is about $0.6 \mathrm{~km}$ southeast of Maryvale, trends N. $30^{\circ}$ W., dips $70^{\circ}$ to the northeast, and displaces a white, tuffaceous, siltstone bed. The lateral extent and total displacement of this fault are not known. The Troublesome Formation overlies Proterozoic basement in many areas, but limited subsurface lithologic data near Fraser and Tabernash suggest that in some areas it overlies Mesozoic shale, which is not exposed in the Fraser quadrangle.

The inferred fault beneath the valley of Vasquez Creek might extend into the Fraser basin beneath Quaternary deposits and, if so, may have played a role in the formation of the basin. This Vasquez Pass fault intersects a complex of local 
faults that offset the Oligocene Red Mountain intrusive system south of the Fraser quadrangle (Eppinger and others, 1985; Geraghty and others, 1988). Tilting of as much as $25^{\circ}$ appears to have occurred since latest Oligocene time (Geraghty and others, 1988; Geissman and others, 1992).

Following the deposition of the Troublesome Formation during the late Oligocene to late Miocene, the rest of the Miocene and the Pliocene appear to have been chiefly a time of widespread erosion in upland areas of the Front Range and stream incision along the flanks of the Front Range and in the adjacent basins. This erosion and stream incision was probably due in part to climate change (Chapin, 2008) as well as ongoing epeirogenic uplift of the Southern Rocky Mountain region (Eaton, 2008).

Hills on the west side of the present course of the Williams Fork, near its confluence with the Colorado River (fig. 2), are capped by at least $30 \mathrm{~m}$ of weakly consolidated cobbly gravel and finer-grained fluvial sediments deposited by the Williams Fork (Izett, 1968) in a paleovalley cut into the Troublesome Formation (R.R. Shroba, USGS, unpublished mapping, 2008). Fossil remains of Hemphillian age (late Miocene and early Pliocene; Robinson, 1968, 1972; Kihm and Middleton, 1980) near the top of these fluvial sediments suggest that the courses of the Williams Fork and Colorado River in the Troublesome basin, and likely the Fraser River in the Granby and Fraser basins, were established after the deposition of the Troublesome Formation during the late Miocene or early Pliocene. Prior to the development of through-flowing drainage across the Gore Range at Gore Canyon (fig. 1), the Fraser River probably flowed on or near the depositional top of the Troublesome Formation above an altitude of 2,990 $\mathrm{m}$ in the southern part of the Fraser basin, and above 2,800 m near the southern part of the Granby basin. The Fraser River has subsequently cut the narrow, deep canyon (locally as much as $300 \mathrm{~m}$ ) in Proterozoic bedrock between Tabernash and Granby, and removed much of the Troublesome Formation from the Fraser and Granby basins. The reach of the river cut in the resistant Proterozoic bedrock, rather than in adjacent more easily eroded sedimentary rocks, suggests that the Fraser River is a superimposed stream.

Erosion during the Pliocene may have been fostered by climatic conditions in the western United States that were significantly wetter (more effective precipitation) and stormier than those of today, particularly about 4.5-3.5 Ma (Forester, 1991) and 3.2-2.8 Ma (Smith and others, 1993). At about $3 \mathrm{Ma}$ there were significant increases in the magnitude of temperature ranges during cold (glacial)/warm (interglacial) climatic cycles (Morrison, 1991), which culminated in the development of major northern hemisphere ice sheets at about 2.7-2.4 Ma (for example, Shackleton and others, 1984; Balco and others, 2005), or possibly as early as $3.2 \mathrm{Ma}$ (Prell, 1984) or 3.6 Ma (Mudelsee and Raymo, 2005). Erosion rates on upland surfaces in Front Range canyons and in adjacent basins are likely linked to, and were likely enhanced by, erosional processes that were intensified by global cooling during the Pliocene and Pleistocene.
The oldest surficial deposits in the Fraser quadrangle are bouldery stream gravel $(\mathrm{QNg})$, of early Pleistocene or Pliocene age, that mantle two ridges about $2 \mathrm{~km}$ northeast and $3 \mathrm{~km}$ north of the Winter Park Ski Area. Their age is uncertain, but they may be correlative with the boulder conglomerate of Pliocene(?) age in the nearby Trail Mountain quadrangle (Izett, 1974).

Quaternary deposits and landforms within the Fraser quadrangle reflect the influence of earth-surface processes in concert with global climate-driven glacial-interglacial cycles during the past 1.8 m.y. Global climatic cooling during the Pliocene continued into the Pleistocene and intensified after about $900 \mathrm{ka}$ (Clark and Pollard, 1998). Pleistocene glacial deposits in Colorado and elsewhere in the Rocky Mountains are commonly correlated with Pinedale, Bull Lake, and preBull Lake glaciations (Meierding and Birkeland, 1980; Pierce, 2004). Blackwelder (1915) named the Pinedale (last major) and Bull Lake (penultimate) glaciations for younger and older sets of moraines and corresponding tills on the eastern and western flanks of the Wind River Range in northwestern Wyoming. Glacial deposits that predated the Bull Lake glaciation typically lack morainal form, and are locally preserved just beyond the outer limits of Pinedale and Bull Lake deposits (Meierding and Birkeland, 1980), such as those near Lake Granby, about $20 \mathrm{~km}$ north of the Fraser quadrangle (Meierding, 1977; Cole and Braddock, 2009).

The youngest glacial deposits near the Fraser quadrangle are tills of latest Pleistocene age (about 10-12 ka; Davis 1988) and Holocene age (Benedict 1985; Benson and others, 2007). These tills typically form sharp-crested moraines above present treeline (about 3,350 m), within roughly 1 $\mathrm{km}$ of cirque head walls. They were deposited during minor glacial advances after the Pinedale glaciation, during marine oxygen isotope (MIS) stage 1, (0-14 ka; Lisiecki and Raymo, 2005). Some of the older, post-Pinedale moraines probably correlate with those of the Satanta Peak advance of Benedict $(1973,1985)$ in the Arapahoe Pass area, in the Monarch Lake 7.5-minute quadrangle, about $8 \mathrm{~km}$ northeast of the Fraser quadrangle. Deposits of the Satanta Peak advance have minimum-limiting radiocarbon ages of $9,915 \pm 380 \mathrm{yr}$ B.P. and $9,700 \pm 215$ yr B.P. (Benedict, 1973), and probably date from 12 to $10 \mathrm{ka}$ B.P. (Benedict, 1985). They probably are coeval with glacial deposits formed during the Younger Dryas climatic event $\left(11,000-10,000{ }^{14} \mathrm{C}\right.$ yr B.P.) in northwestern North America and northern Europe (Menounos and Reasoner, 1997).

Except for a few scattered till-like deposits (diamictons in unit Qgd) along Saint Louis Creek and Elk Creek, about 4-5 km southwest of Fraser, there are no known exposed glacial deposits of pre-Bull Lake age within the Fraser quadrangle. However, much of the till of Bull Lake age (Otb) along Ranch Creek lacks morainal form and locally may include till of preBull Lake age. The sparse distribution of glacial deposits of pre-Bull Lake age in the Front Range and near the margins of adjacent basins probably is due, in part, to erosion and subsequent burial by deposits of younger and more extensive glacial advances (Meierding and Birkeland, 1980). Glacial deposits 
of early Pleistocene age are likely to be buried by younger glacial deposits, because only two glacial episodes (12 and 16, Lisiecki and Raymo, 2005) were as severe - in terms of temperature and global ice volume - as those during the Bull Lake and Pinedale glaciations. This suggests that deposits of pre-Bull Lake glaciations other than those that accumulated during MIS 12 and 16 are likely to be less extensive than, and are probably buried by, deposits of the Bull Lake and Pinedale glaciations. Some of the coarse cobbly stream gravel in unit Qgd as well as some of the older deposits of gravelly streamterrace alluvium $\left(\mathrm{Qg}_{3-6}\right.$ and $\left.\mathbf{Q g}_{8}\right)$ may be outwash gravel deposited during pre-Bull Lake glaciations.

The oldest glacial deposits in the Fraser quadrangle that have preserved morainal morphology are till and, locally, minor deposits of stratified drift, which form subdued moraines of the Bull Lake glaciation. Bull Lake deposits in their type area in northwestern Wyoming are about 170$120 \mathrm{ka}$ (Sharp and others, 2003; Pierce, 2004). These deposits accumulated during one or more major cold climatic episodes during MIS 6 (190-130 ka; Lisiecki and Raymo, 2005) and probably during the early part of MIS 5 (Pierce, 2004). Till and minor stratified drift of the Pinedale glaciation form well preserved moraines in glaciated valleys in and near the Fraser quadrangle. Pinedale glacial deposits in Colorado are about 30-12 ka (Nelson and others, 1979; Madole, 1986; Schildgen and Dethier, 2000; Benson and others, 2004, 2005). They accumulated during a major cold climatic episode during MIS 2 (35-14 ka; Lisiecki and Raymo, 2005). Till and other icecontact deposits of the Pinedale glaciation locally may include or overlie glacial deposits of early Wisconsin age (MIS 4, 70-55 ka; Lisiecki and Raymo, 2005), which have been identified in a few areas of the western United States (Pierce, 2004). Till briefly exposed in a deep excavation at the Mary Jane site (in the Winter Park Ski Area, just south of Fraser quadrangle; fig. 1), is older than 30,480 and $30,050{ }^{14} \mathrm{C}$ yr B.P. (Nelson and others, 1979). It may be early Wisconsin in age (Richmond, 1986; Richmond and Fullerton, 1986b) or may have been deposited during an early advance of Pinedale ice (Sturchio and other, 1994). This till is overlain by three thin $(30-50 \mathrm{~cm})$ till-derived debris-flow deposits that accumulated during the Pinedale glaciation as well as by interstratified silty lake sediments, all of which are older than $13,740{ }^{14} \mathrm{C}$ yr B.P. (Short and Elias, 1987).

The aerial and altitudinal distribution of till in and near the Fraser quadrangle suggests that glaciers during the Bull Lake and Pinedale glaciations were about $8-18 \mathrm{~km}$ in length, typically descended to elevations of about $2,610-2,745 \mathrm{~m}$, and probably were at least $120-245 \mathrm{~m}$ thick. By comparison, glaciers during the Bull Lake and Pinedale glaciations throughout the Front Range typically attained lengths of $10-20 \mathrm{~km}$, terminated at elevations between 2,500 and 2,700 $\mathrm{m}$, and were 180-350 m thick (Benson and others, 2004).

Snow lines during the Pleistocene in the western United States were roughly 1,000 m lower than present (Porter and others, 1983). Fossil beetles at the Mary Jane site (2,882 m), dated at 13,200 and $12,800{ }^{14} \mathrm{C}$ yr B.P., suggest that during full- or late-glacial climatic conditions mean July temperatures were $3-4{ }^{\circ} \mathrm{C}$ colder than present and January mean temperatures were $19-21^{\circ} \mathrm{C}$ colder than present (Elias, 1996; table 4 this report).

More effective precipitation and vigorous freeze-thaw action likely accompanied expanded periglacial environments during glacial episodes, and would have promoted slope instability and intensified mass-movement processes in the Front Range and the adjacent Fraser basin. Weakly consolidated material, such as siltstone in the Troublesome Formation, was particularly prone to mass-movement processes such as creep and solifluction. Much of the coarse debris, which form features such as block fields and block streams on interfluves above present treeline in areas adjacent to the Fraser quadrangle, probably formed chiefly under periglacial conditions. Increased infiltration of atmospheric precipitation may have locally promoted deep-seated rock creep beneath steep slopes in periglacial environments.

Streams draining from glaciers within and near the Fraser quadrangle produced broad, gravelly deposits of glacial outwash, particularly during times of significantly greater sediment yield during deglaciation (Church and Ryder, 1972). Some of the glacial outwash may be slightly younger than corresponding tills, because significant fluvial deposition may have lagged (perhaps by a few to several thousand years) the transition from glacial to interglacial climates (Church and Ryder, 1972; Hancock and Anderson, 2002). Large deposits of glacial outwash in the Fraser quadrangle, such as units $\mathbf{O g}_{1}$ and $\mathrm{Og}_{2}$ in the valley of the Fraser River, locally extend 12 $\mathrm{km}$ or more downstream of former glacier fronts. Maximum grain size and the slope of the depositional tops of glacial outwash deposits decrease significantly within a distance of about $10 \mathrm{~km}$ downstream of former glacier fronts (Church and Ryder, 1972; Ritter, 1987).

Alluvium of Holocene age in present stream channels and in flood plains less than $5 \mathrm{~m}$ above present streams are difficult to correlate with climatic episodes, but some episodes of alluvial deposition may reflect past climatic conditions that were colder than, and possibly more moist (or had more effective precipitation) than the present climate. Cooler climatic episodes during the Holocene promoted glacial and (or) periglacial activity in the Front Range (Scott, 1975).

Table 4. Mean January and July temperatures near Fraser, Colo., and estimated mean January and July temperatures near the Mary Jane site, about $9 \mathrm{~km}$ southeast of Fraser.

\begin{tabular}{lccc}
\hline $\begin{array}{l}\text { Weather station } \\
\text { or site name }\end{array}$ & $\begin{array}{c}\text { Approximate } \\
\text { elevation } \\
(\mathbf{m})\end{array}$ & $\begin{array}{c}\text { Mean January } \\
\text { temperature } \\
\left({ }^{\circ} \mathbf{C}\right)\end{array}$ & $\begin{array}{c}\text { Mean July } \\
\text { temperature } \\
\left({ }^{\circ} \mathbf{C}\right)\end{array}$ \\
\hline Fraser $^{1}$ & 2,610 & -11.0 & 12.2 \\
Mary Jane site & 2,882 & -12.8 & 10.4 \\
\hline${ }^{1}$ Value for Fraser (1959-1974) are from Hansen and others $(1978)$. \\
${ }^{2}$ Values for the Mary Jane site were estimated by decreasing the mean January and \\
July temperatures for Fraser by $1.8^{\circ} \mathrm{C}$, assuming an environmental lapse rate of $6.5^{\circ} \mathrm{C}$ per \\
$1,000 \mathrm{~m}$ (Meierding, 1982).
\end{tabular}


One deposit of loess, too small to show on the map, mantles gravelly stream-terrace alluvium of middle Pleistocene age $\left(\mathrm{Qg}_{3}\right)$, just south of Tabernash. Thin loess deposits locally may overlie, or were redeposited, as silty overbank deposits that mantle some of the other deposits of gravelly stream-terrace alluvium. Thin $(\leq 50 \mathrm{~cm})$ deposits of reworked loess (clayey silt) are locally present in wet alpine meadows and bogs above treeline, south and southwest of the Fraser quadrangle (Retzer, 1962). Geochemical composition and grain-size data suggest that alluvial silt in Middle Park and possibly North Park is are a likely source for the eolian silt that is present in A horizons of alpine soils in the Indian Peaks Wilderness Area, about $6 \mathrm{~km}$ east of the Fraser quadrangle (Muhs and Benedict, 2006).

\section{Acknowledgments}

This report was much improved by comments by Paul E. Carrara and James C. Cole, U.S. Geological Survey. Cole provided recalculated radiometric ages for several rock units listed in Marvin and others (1974), adjusted to the revised decay constants of Steiger and Jäger (1977). We thank Tom Kalan of the Winter Park West Water and Sanitation District for providing subsurface data for the district's water wells near Fraser, Colo.

\section{References Cited}

Aleinikoff, J.N., Reed, J.C., Jr., and Wooden, J.L., 1993, Lead isotopic evidence for the origin of Paleo- and Mesoproterozoic rocks of the Colorado Province, U.S.A.: Precambrian Research, v. 63, p. 97-122.

Balco, Greg, Rovey, C.W., II, and Stone, J.O.H., 2005, The first glacial maximum in North America: Science, v. 307, doi:10.1126/Science.1103406, p. 222.

Bauch, N.J., and Bails, J.B., 2003, Water-quality characteristics and ground-water quality of the Fraser River watershed, Grand County, Colorado: U.S. Geological Survey WaterResources Investigations Report 03-4275, 57 p.

Benedict, J.B., 1973, Chronology of cirque glaciation, Colorado Front Range: Quaternary Research, v. 3, p. 585-599.

Benedict, J.B., 1985, Arapaho Pass-Glacial geology and archeology at the crest of the Colorado Front Range: Ward, Colo., Center for Mountain Archeology, Research Report no. 3,197 p.
Benson, Larry, Madole, Richard, Kubik, Peter, and McDonald, Richard, 2007, Surface-exposure ages of Front Range moraines that may have formed during the Younger Dryas, 8.2 cal ka, and Little Ice Age events: Quaternary Science Reviews, v. 26, p. 1638-1649.

Benson, Larry, Madole, Richard, Landis, Gary, and Gosse, John, 2005, New data for late Pleistocene alpine glaciation from southwestern Colorado: Quaternary Science Reviews, v. 24 , p. $46-65$.

Benson, Larry, Madole, Richard, Phillips, William, Landis, Gary, Thomas, Terry, and Kubic, Peter, 2004, The probable importance of snow and sediment shielding on cosmogenic ages of north-central Colorado Pinedale and pre-Pinedale moraines: Quaternary Science Reviews, v. 23, p. 193-206.

Birkeland, P.W., 1999, Soils and geomorphology: New York, Oxford University Press, 430 p.

Blackwelder, Eliot, 1915, Post-Cretaceous history of the mountains of central western Wyoming: Journal of Geology, v. 23, p. 97-117, 193-217, 307-340.

Braddock, W.A., and Cole, J.C., 1990, Geologic Map of Rocky Mountain National Park and vicinity, Colorado: U.S. Geological Survey Miscellaneous Investigations Series Map I-1973, scale 1:50,000.

Bryant, Bruce, McGrew, L.W., and Wobus, R.A., 1981, Geologic map of the Denver $1^{\circ} \times 2^{\circ}$ quadrangle, north-central Colorado: U.S. Geological Survey Miscellaneous Investigations Series I-1163, scale 1:250,000.

Buffler, R.T., 2003, The Browns Park Formation in the Elkhead region, northwestern Colorado-south central Wyoming-Implications for late Cenozoic sedimentation, in Raynolds, R.G., and Flores, R.M., eds., Cenozoic systems of the Rocky Mountain Region/Rocky Mountain Section, SEPM (Society for Sedimentary Geology): Denver, Colorado, The Rocky Mountain section of Society for Sedimentary Geology, p. 183-212.

Cather, S.M., Connell, S.D., Chamberlin, R.M., McIntosh, W.C., Jones, G.E., Potochnik, A.R., Lucas, S.G., and Johnson, P.S., 2008, The Chuska erg-Paleogeomorphic and paleoclimatic implications of an Oligocene sand sea on the Colorado Plateau: Geological Society of America Bulletin, v. 120 , p. $13-33$.

Chapin, C.E., 2008, Interplay of oceanographic and paleoclimate events with tectonism during middle to late Miocene sedimentation across the southwestern USA: Geosphere, v. 4, no., 6, p. 976-991. 
Chapin, C.E., and Cather, S.M., 1994, Tectonic setting of the axial basins of the northern and central Rio Grande rift, in Keller, G.R., and Cather, S.M., eds., Basins of the Rio Grande rift-Structure, stratigraphy, and tectonic setting: Geological Society of America Special Paper 291-I, p. 5-25.

Chapin, C.E., and Kelley, S.A., 1997, The Rocky Mountain erosion surface in the Front Range of Colorado, in Bolyard, D.W. and Sonnenberg, S.A., eds., Geologic history of the Colorado Front Range, Colorado: Denver, Colo., The Rocky Mountain Association of Geologists, 1997 RMS-AAPG field trip no. 7 [guidebook], p. 101-113.

Chapin, C.E., and Lindley, J.I., 1986, Potassium metasomatism of igneous and sedimentary rocks in detachment terranes and other sedimentary basins - Economic implications, in Beatty, B. and Wilkinson, P.A.K., eds., Frontiers in geology and ore deposits of Arizona and the southwest: Arizona Geological Society Digest, v. 16, p. 118-126.

Church, Michael, and Ryder, J.M., 1972, Paraglacial sedimentation-A consideration of fluvial processes conditioned by glaciation: Geological Society of America Bulletin, v. 83, p. 3059-3072.

Clark, P.U., and Pollard, David, 1998, Origin of the middle Pleistocene transition by ice sheet erosion of regolith: Paleoceanography, v. 13, p. 1-9.

Cole, J.C., and Braddock, W.A., 2009, Geologic map of the Estes Park 30' × 60' quadrangle, north-central Colorado: U.S. Geological Survey Scientific Investigations Map 3039, scale 1:100,000, 56-p. pamphlet (also available at URL http://pubs.usgs.gov/sim/3039/).

Cole, J.C., Larson, Ed, Farmer, Lang, and Kellogg, K.S., 2008, The search for Braddock's caldera-Guidebook for the Colorado Scientific Society Fall 2008 field trip, Never Summer Mountains, Colorado: U.S. Geological Survey OpenFile Report 2008-1360, 30 p. (also available at http://pubs. usgs.gov/of/2008/1360/).

Colorado Division of Water Resources, 2007, Colorado's WellView Web: Colorado Department of Natural Resources, Colorado Division of Water Resources, 1313 Sherman St., Denver, Colo. [Available at http://www.dwr.state.co.us/WellViewWeb/].

Davis, P.T., 1988, Holocene glacier fluctuations in the American Cordillera: Quaternary Science Reviews, v. 7, p. 129-157.

DeVoto, R.H., 1980, Pennsylvanian stratigraphy and history of Colorado, in Kent, H.C., and Porter, K.W., eds., Colorado Geology: Rocky Mountain Association of Geologists, Denver, p. 71-101.
Eaton, G.P., 2008, Epeirogeny in the Southern Rocky Mountains region-Evidence and origin: Geosphere, v. 4, no., 5, p. 764-784.

Elias, S.A., 1996, Late Pleistocene and Holocene seasonal temperature reconstructed from fossil beetle assemblages in the Rocky Mountains: Quaternary Research, v. 46, p. 311-318.

Eppinger, R.G., Theobald, P.K., and Carlson, R.R., 1985, Generalized geologic map of the Vasquez Peak Wilderness Study Area and the William Fork and St. Louis Peak Roadless Areas, Clear Creek, Grand, and Summit Counties, Colorado: U.S. Geological Survey Miscellaneous Studies Map MF-1588B, scale 1:50,000.

Evanoff, Emmett, 1990, Early Oligocene paleovalleys in southern and central Wyoming-Evidence of high local relief on the late Eocene unconformity: Geology, v. 18, p. $443-446$.

Feth, J.H., 1964, Review and annotated bibliography of ancient lake deposits (Precambrian to Pleistocene) in the western states: U.S. Geological Survey Bulletin 1080, 119 p.

Folk, R.L., 1965, Petrology of sedimentary rocks: Austin, Texas, Hemphill Publishing Co., 159 p.

Forester, R.M., 1991, Pliocene-climate history of the western United States derived from lacustrine ostracodes: Quaternary Science Reviews, v. 10, p. 133-146.

Geissman, J.W., Snee, L.W., Grasskamp, G.W., Carten, R.B., and Geraghty, E.P., 1992, Deformation and age of the Red Mountain intrusive system (Urad-Henderson molybdenum deposits), Colorado_Evidence from paleomagnetic and ${ }^{40} \mathrm{Ar} /{ }^{39} \mathrm{Ar}$ data: Geological Society of America Bulletin, v. 104 , p. $1031-1047$.

Geraghty, E.F., Carten, R.B., and Walker. B.W., 1988, Tilting of Urad-Henderson and Climax porphyry molybdenum systems, central Colorado, as related to northern Rio Grande rift tectonics: Geological Society of America Bulletin, v. 100 , p. $1780-1786$.

Hancock, G.S., and Anderson, R.S., 2002, Numerical modeling of fluvial strath-terrace formation in response to oscillating climate: Geological Society of America Bulletin, v. 114, p. 1131-1142.

Hansen, W.R., 1984, Post-Laramide tectonic history of the eastern Uinta Mountains, Utah: The Mountain Geologist, v. 21 , p. 5-29.

Hansen, W.R., Chronic, John, and Matelock, John, 1978, Climatology of the Front Range urban corridor and vicinity, Colorado: U.S. Geological Survey Professional Paper 1019, $59 \mathrm{p}$. 
Hilgard, E.W., 1892, A report on the relations of soil to climate: U.S. Department of Agriculture, Weather Bureau Bulletin 3, 59 p.

Hunt, R.M., Jr., 1990, Taphonomy and sedimentology of Arikaree (lower Miocene) fluvial, eolian, and lacustrine paleoenvironments, Nebraska and Wyoming: A paleobiota entombed in fine-grained volcaniclastic rocks, in Lockley, M.G., and Rice, A., eds., Volcanism and fossil biota: Geological Society of America Special Paper 244, p. 69-111.

Izett, G.A., 1968, Geology of the Hot Sulphur Springs quadrangle, Grand County, Colorado: U.S. Geological Survey Professional Paper 586, 79 p., map scale 1:62,500.

Izett, G.A., 1974, Geologic map of the Trail Mountain quadrangle, Grand County, Colorado: U.S. Geological Survey Geologic Quadrangle Map GQ-1156, scale 1:24,000.

Izett, G.A., 1975, Late Cenozoic sedimentation and deformation in northern Colorado and adjoining areas, in Curtis, B.F., ed., Cenozoic history of the southern Rocky Mountains: Geological Society of America Memoir 144, p. 179-209.

Izett, G.A., and Barclay, C.S.V., 1973, Geologic map of the Kremmling quadrangle, Grand County, Colorado: U.S. Geological Survey Geologic Quadrangle Map GQ-1115, scale $1: 62,500$.

Izett, G.A., and Obradovich, J.D., 2001, ${ }^{40} \mathrm{Ar} /{ }^{39} \mathrm{Ar}$ ages of Miocene tuffs in basin-fill deposits (Santa Fe Group, New Mexico, and Troublesome Formation, Colorado) of the Rio Grande rift system: The Mountain Geologist, v. 38, p. 77-86.

Johannes, W., and Gupta, L.N., 1982, Origin and evolution of a migmatite: Contributions to Mineralogy and Petrology, v. 79 , p. 114-123.

Kellogg, K.S., 1998, Neogene basins of the northern Rio Grande rift-Partitioning and asymmetry inherited from Laramide and older uplifts: Tectonophysics, v. 305, p. 141-152.

Kellogg, K.S., Shroba, R.R., Bryant, Bruce, and Premo, W.R., 2008, Geologic map of the Denver West $30^{\prime} \times 60^{\prime}$ quadrangle, north-central Colorado: U.S. Geological Survey Scientific Investigations Map 3000, scale 1:100,000, 48-p. pamphlet (also available at URL http://pubs.usgs.gov/ $\operatorname{sim} / 3000 /)$.

Kihm, A.J., and Middleton, M.D., 1980, Tertiary vertebrate biostratigraphy of Colorado, in Kent, H.C., and Porter, K.W., eds., Colorado geology: Rocky Mountain Association of Geologists Symposium Proceedings, Denver, Colo., p. $157-163$.

Knox, K.L., 2005, Never Summer igneous complex-Evolution of a shallow magmatic system: Boulder, Colo., University of Colorado, M.S. Thesis, 54 p.
Kron, D.G., 1988, Miocene mammals from the central Colorado Rocky Mountains: Boulder, Colo., University of Colorado, Ph.D. dissertation, 364 p.

Lisiecki, L.E., and Raymo, M.E., 2005, A Pliocene-Pleistocene stack of 57 globally distributed benthic $\delta^{18} \mathrm{O}$ records: Paleoceanography, v. 20, PA1003, doi:10.1029/2004PA001071, $17 \mathrm{p}$.

Luft, S.J., 1985, Airfall tuff in the Browns Park Formation, northwestern Colorado and northeastern Utah: The Mountain Geologist, v. 22, p. 110-127.

Madole, R.F., 1986, Lake Devlin and Pinedale glacial history, Front Range, Colorado: Quaternary Research, v. 25, p. 43-54.

Marvin, R.F., Young, E.J., Mehnert, H.H., and Naeser, C.W., 1974, Summary of radiometric age determinations on Mesozoic and Cenozoic igneous rocks and uranium and base metal deposits in Colorado: Isochron West, no. 11, 41 p.

McCoy, A.M., Karlstrom, K.E., Shaw, C.A., and Williams, M.L., 2005, The Proterozoic ancestry of the Colorado Mineral Belt-1.4 Ga shear zone system in central Colorado, in Karlstrom, K.E. and Keller, G.R., eds., The Rocky Mountain region-An evolving lithosphere; tectonics, geochemistry, and geophysics: American Geophysical Union Geophysical Monograph 154, p. 71-90.

Meierding, T.C., 1977, Age differentiation of till and gravel deposits in the upper Colorado River basin: Boulder, Colo., University of Colorado, Ph.D. dissertation, 353 p.

Meierding, T.C., 1982, Late Pleistocene glacial equilibriumline altitudes in the Colorado Front Range - A comparison of methods: Quaternary Research, v. 18, p. 289-310.

Meierding, T.C., and Birkeland, P.W., 1980, Quaternary glaciation of Colorado, in Kent, H.C., and Porter, K.W., eds., Colorado geology: Rocky Mountain Association of Geologists Symposium Proceedings, Denver, Colo. p. 165-173.

Menounos, Brian, and Reasoner, M.A., 1997, Evidence for cirque glaciation in the Colorado Front Range during the Younger Dryas chronozone: Quaternary Research, v. 48, p. $38-47$.

Merrill, G.P., 1897, A treatise on rocks, rock-weathering and soils: New York, N.Y., Macmillan Company, 411 p.

Meyer, G.A., and Wells, S.G., 1997, Fire-related sedimentation events on alluvial fans, Yellowstone National Park, U.S.A.: Journal of Sedimentary Research, v. 67, p. 776-791.

Morrison, R.B., 1991, Introduction, chap. 1, in Morrison, R.B., ed., Quaternary nonglacial geology-Conterminous U.S.: Geological Society of America, The geology of North America, v. K-2, p. 1-12. 
Mudelsee, Manfred, and M. E. Raymo, 2005, Slow dynamics of the Northern Hemisphere glaciation: Paleoceanography, vol. 20, no. 4, PA4022, doi:10.1029/2005PA001153, 14 p.

Muhs, D.R., and Benedict, J.B., 2006, Eolian additions to late Quaternary alpine soils, Indian Peaks Wilderness area, Colorado Front Range: Arctic, Antarctic, and Alpine Research, v. 38 , p. $120-130$.

Munsell Color, 1973, Munsell soil color charts: Baltimore, Md., Kollmorgen Corp., Macbeth Division.

Naeser, C.W., Bryant, Bruce, Kellogg, Karl, Donelick, R.A., and Perry, W.J., Jr., 2002, Tertiary cooling and tectonic history of the White River uplift, Gore Range, and western Front Range, central Colorado-Evidence from fissiontrack and ${ }^{39} \mathrm{Ar} /{ }^{40} \mathrm{Ar}$ ages, in Kirkham, R.M., Scott, R.B., and Judkins, T.W., eds., Late Cenozoic evaporite tectonism and volcanism in west-central Colorado: Boulder, Colo., Geological Society of America Special Paper 366, p. 31-53.

Nelson, A.R., Millington, A.C., Andrews, J.T., and Nichols, H., 1979, Radiocarbon-dated upper Pleistocene glacial sequence, Fraser Valley, Colorado Front Range: Geology, v. 7, p. $410-414$.

North American Commission on Stratigraphic Nomenclature, 1983, North American stratigraphic code: American Association of Petroleum Geologists Bulletin, v. 67, p. 841-875.

Olsen, S.N., 1982, Open- and closed-system migmatites in the Front Range, Colorado: American Journal of Science, v. 282, p. 1596-1622.

Peterson, O.A., 1907, The Miocene beds of western Nebraska and eastern Wyoming and their vertebrate faunae: Carnegie Museum Annals, v. 4, no. 1, p. 21-27.

Peterson, O.A., 1909, A revision of the Entelodontidae: Carnegie Museum Memoir, v. 4, no. 3, p. 41-158.

Picard, M.D., and High, L.R., Jr., 1981, Physical stratigraphy of ancient lacustrine deposits, in Ethridge, F.G., and Flores, R.M., eds., Recent and ancient nonmarine environmentsModels for exploration: Tulsa, Okla., The Rocky Mountain Section, Society of Economic Paleontologists and Mineralogists, Special Publication no. 31, p. 209-229.

Pierce, K.L., 2004, Pleistocene glaciation of the Rocky Mountains, in Gillespie, A.R., Porter, S.C., and Atwater, B.F., eds., The Quaternary Period in the United States: Amsterdam, Elsevier, p. 63-76.
Pierson, T.C., and Costa, J.E., 1987, A rheologic classification of subaerial sediment-water flows, in Costa, J.E., and Wieczorek, G.F., eds., Debris flows/Avalanches-Process, recognition, and mitigation: Geological Society of America, Reviews in Engineering Geology, v. 7, p. 1-12.

Porter, S.C., Pierce, K.L., and Hamilton, T.D., 1983, Late Wisconsin mountain glaciation in the western United States, in Porter, S.C., ed., Late-Quaternary environments of the United States, v. 1, The late Pleistocene: Minneapolis, Minn., University of Minnesota Press, p. 71-111.

Prell, W.A., 1984, Covariance patterns of foraminifera $\delta^{18} \mathrm{O}-$ An evaluation of Pliocene ice volume changes near 3.2 million years ago: Science, v. 206, p. 692-693.

Premo, W.R., Kellogg, K.S., Castiñeiras, Pedro, Bryant, Bruce, and Moscati, R.J., 2007, New SHRIMP zircon ages and $\mathrm{Nd}$ signatures from central Colorado Front Range migmatite and related igneous rocks - Implications for the timing and origin of crustal growth: Geological Society of America Abstracts with Programs, v. 39, no. 5, p. 36.

Premo, W.R., and Van Schmus, W.R., 1989, Zircon geochronology of Precambrian rocks in southeastern Wyoming and northern Colorado, in Grambling, J.A., and Tewksbury, B.J., eds., Geology of the southern Rocky Mountains: Geological Society of America Special Paper 235, p. 13-32.

Pye, Kenneth, 1987, Aeolian dust and dust deposits: London, Academic Press, 334 p.

Pye, Kenneth, 1995, The nature, origin and accumulation of loess: Quaternary Science Reviews, v. 14, p. 653-667.

Reed, J.C., Jr., Bickford, M.E., Premo, W.R., Aleinikoff, J.N., and Pallister, J.S., 1987, Evolution of the Early Proterozoic Colorado province - Constraints from U-Pb geochronology: Geology, v. 15, p. 861-865.

Retzer, J.L., 1962, Soil survey Fraser alpine area Colorado: Washington, D.C., U.S. Department of Agriculture, Forest Service and Soil Conservation Service in cooperation with Colorado Agricultural Experiment Station, series 1956, no. $20,47 \mathrm{p}$.

Richmond, G.M., 1986, Stratigraphy and correlation of glacial deposits of the Rocky Mountains, the Colorado Plateau, and the ranges of the Great Basin, in Richmond, G.M., and Fullerton, D.S., eds., Quaternary glaciations in the United States of America: Quaternary Science Reviews, v. 5, p. $99-127$. 
Richmond, G.M., and Fullerton, D.S., 1986a, Introduction to Quaternary glaciations in the United States of America, in Richmond, G.M., and Fullerton, D.S., eds., Quaternary glaciations in the United States of America: Quaternary Science Reviews, v. 5, p. 3-10.

Richmond, G.M., and Fullerton, D.S., 1986b, Summation of Quaternary glaciations in the United States of America, in Richmond, G.M., and Fullerton, D.S., eds., Quaternary glaciations in the United States of America: Quaternary Science Reviews, v. 5, p. 183-196.

Ritter, D.F., 1987, Fluvial processes in the mountains and intermontane basins, in Graf, W.L., ed., Geomorphic systems of North America: Geological Society of America, Centennial Special v. 2, Boulder, Colo., p. 220-228.

Robinson, Peter, 1968, Comments on the smaller mammals of Miocene age from Middle Park, Colorado, in Black, C.C., McKenna, M.C., and Robinson, Peter, eds., Field conference guidebook for the high altitude and mountain basin deposits of Miocene age in Wyoming and Colorado: Boulder, Colorado, University of Colorado Museum, Boulder, p. 194-203.

Robinson, Peter, 1972, Tertiary history, in Mallory, W.W., ed., Geologic atlas of the Rocky Mountain region: Denver, Colo., Hirschfeld Press, Rocky Mountain Association of Geologists, p. 233-242.

Schildgen, T.F., and Dethier, D.P., 2000, Fire and ice-Using isotopic dating techniques to infer the geomorphic history of Middle Boulder Creek, Colorado: Geological Society of America Abstracts with Programs, v. 32, no. 7, p. A18.

Schildgen, Taylor, Dethier, D.P., Bierman, Paul, and Caffee, Marc, 2002, ${ }^{26} \mathrm{Al}$ and ${ }^{10} \mathrm{Be}$ dating of late Pleistocene and Holocene fill terraces - A record of fluvial deposition and incision, Colorado Front Range: Earth Surface Process and Landforms, v. 27, p. 773-787.

Schroeder, D.A., 1995a, Geologic map of the Strawberry Lake quadrangle, Grand County, Colorado: U.S. Geological Survey, Geologic Quadrangle Map GQ-1764, scale 1:24,000.

Schroeder, D.A., 1995b, Geologic map of the Granby quadrangle, Grand County, Colorado: U.S. Geological Survey, Geologic Quadrangle Map GQ-1763, scale 1:24,000.

Scott, G.R., 1975, Cenozoic surfaces and deposits in the Southern Rocky Mountains, in Curtis, B.F., ed., Cenozoic history of the Southern Rocky Mountains: Geological Society of America Memoir 144, p. 227-248.

Shackleton, N.J., Backman, J., Zimmerman, H., and 14 others, 1984, Oxygen isotope calibration of the onset of ice-rafting and history of glaciation in the North Atlantic region: Nature, v. 307, p. 620-623.
Shannon, J.R., Nelson, E.P., and Golden, R.J., Jr., 2004, Surface and underground geology of the world-class Henderson molybdenum porphyry mine, Colorado, in Nelson, E.P., and Erslev, E.A., eds., Field trips in the southern Rocky Mountains: Boulder, Colo., Geological Society of America Field Guide 5, p. 207-218.

Sharp, W.D., Ludwig, K.R., Chadwick, O.A., Amundson, Ronald, and Glaser, L.L., 2003, Dating fluvial terraces by ${ }^{230} \mathrm{Th} / \mathrm{U}$ on pedogenic carbonate, Wind River basin, Wyoming: Quaternary Research, v. 59, p. 139-150.

Shaw, C.A., Karlstrom, K.E., McCoy, Annie, Williams, M.L., Jercinovic, M.J., and Dueker, Ken, 2002, Proterozoic shear zones in the Colorado Rocky Mountains-From continental assembly to intracontinental reactivation: Boulder, Colo., Geological Society of America Field Guide 3, p. 102-117.

Short, S.K., and Elias, S.A., 1987, New pollen and beetle analyses at the Mary Jane site, Colorado_Evidence for late glacial conditions: Geological Society of America Bulletin, v. 98 , p. $540-548$.

Shroba, R.R., Rosholt, J.N., and Madole, R.F., 1983, Uraniumtrend dating and soil B horizon properties of till of Bull Lake age, North St. Vrain drainage basin, Front Range, Colorado: Geological Society of America Abstracts with Programs, v. 15 , no. 5, p. 431.

Smith, G.A., Wang, Yang, Cerling, T.E., and Geissman, J.W., 1993, Comparison of a paleosol-carbonate isotope record to other records of Pliocene-early Pleistocene climate in the western United States: Geology, v. 21, p. 691-694.

Soil Survey Staff, 1951, Soil survey manual: U.S. Department of Agriculture Handbook 18, 503 p.

Soil Survey Staff, 1999, Soil taxonomy-A basic system of soil classification for making and interpreting soil surveys: U.S. Department of Agriculture Handbook 436, 2nd ed., 869 p.

Steiger, R.H., and Jäger, E., 1977, Subcommission on geochronology - Convention on the use of decay constants in geo- and cosmochronology: Earth and Planetary Science Letters, v. 36, p. 359-362.

Stein, H.J., and Crock, J.G., 1990, Late Cretaceous-Tertiary magmatism in the Colorado Mineral Belt-Rare earth element and samarium-neodymium isotopic studies, in Anderson, J.L., ed., The nature and origin of Cordilleran magmatism: Geological Society of America Memoir 174, p. 195-223.

Strömberg, C.A.E., 2002, The origin and spread of grassdomimated ecosystems in the late Tertiary of North America-Preliminary results concerning the evolution of hypsodonty: Paleogeography, Paleoclimatology, Paleoecology, v. 177 , p. $59-75$. 
Sturchio, N.C., Pierce, K.L., Murrell, M.T., and Sorey, M.L., 1994, Uranium-series ages of travertines and timing of the last glaciation in the northern Yellowstone area, WyomingMontana: Quaternary Research, v. 41, p. 265-277.

Taylor, B.E., 1971, Precambrian geology of the Byers Peak area, central Front Range, Colorado: Golden, Colorado, Colorado School of Mines, M.S. thesis, 118 p.

Taylor, R.B, 1975, Geologic map of the Bottle Pass quadrangle, Grand County, Colorado: U.S. Geological Survey Geologic Quadrangle Map GQ-1224, scale 1:24,000.

Taylor, R.B., Theobald, P.K., and Izett, G.A., 1968, MidTertiary volcanism in the central Front Range, Colorado, in Epis, R.C., ed., Cenozoic volcanism in the southern Rocky Mountains: Colorado School of Mines Quarterly v. 63, no. 3, p. 39-50.

Tedford, R.H., and Barghoorn, Steven, 1999, Santa Fe Group (Neogene), Ceja del Rio Puerco, northwestern Albuquerque Basin, Sandoval County, New Mexico, in Pazzaglia, F.J., and Lucas, S.G., eds., New Mexico Geological Society Fall field Conference Guidebook 50, Albuquerque Geology, Sept. 22-25. 1999: New Mexico Geological Society Guidebook 50, p. 327-335.

Tedford, R.H. and nine others, 2004, Mammalian biochronology of the Arikareean through Hemphillian interval (late Oligocene through earliest Pliocene epochs), in Woodburne, M.O., ed., Late Cretaceous and Cenozoic mammals of North America: New York, N.Y., Columbia University Press, p. 169-231.

Theobald, P.K., 1965, Preliminary geologic map of the Berthoud Pass quadrangle, Clear Creek and Grand Counties, Colorado: U.S. Geological Survey Miscellaneous Geologic Investigations Map I-443, scale 1:24,000.

Thompson, R.S., Anderson, K.H., and Bartlein, P.J., 1999, Atlas of relations between climatic parameters and distributions of important trees and shrubs in North AmericaHardwoods: U.S. Geological Survey Professional Paper 1650-B, 423 p.

Tweto, Ogden, 1957, Geologic sketch of southern Middle Park, Colorado, in Finch, W.C., ed., Guidebook to the geology of North and Middle Parks basin, Colorado: Denver, Colorado, Rocky Mountain Association of Geologists, p. $18-31$.

Tweto, Ogden, 1975, Laramide (Late Cretaceous-early Tertiary) orogeny in the southern Rocky Mountains, in Curtis, B.F., ed., Cenozoic history of the southern Rocky Mountains: Geological Society of America Memoir 144, p. 1-44.
Tweto, Ogden, 1978, Tectonic map of the Rio Grande rift system in Colorado, in Hawley, J.W., compiler, Guidebook to Rio Grande rift in New Mexico and Colorado: New Mexico Bureau of Mines and Mineral Resources Circular 163, sheet 1, scale 1:1,000,000.

Tweto, Ogden, 1979a, Geologic Map of Colorado: U.S. Geological Survey, scale 1:500,000.

Tweto, Ogden, 1979b, The Rio Grande Rift system in Colorado, in Riecker, R.E., ed., Rio Grande Rift-Tectonics and magmatism: Washington, D.C., American Geophysical Union, p. 33-56.

Tweto, Ogden, 1980, Summary of Laramide orogeny in Colorado, in Kent, H.C., and Porter, K.W., eds., Colorado geology: Rocky Mountain Association of Geologists Symposium Proceedings, Denver, Colo., p. 129-134.

Tweto, Ogden, 1987, Rock units of the Precambrian basement in Colorado: U.S. Geological Survey Professional Paper 1321-A, 54 p.

Tweto, Ogden, and Sims, P.K., 1963, Precambrian ancestry of the Colorado mineral belt: Geological Society of America Bulletin, v. 74, p. 991-1014.

U.S. Geological Survey Geologic Names Committee, 2007, Divisions of geologic time-Major chronostratigraphic and geochronologic units: U.S. Geological Survey Fact Sheet 2007-3015, 2 p.

Varnes, D.J., and Cruden, D.M., 1996, Slope movement types and process, in Schuster, R.L., and Krizek, R.J., eds., Landslide investigation and mitigation: Washington, D. C., National Academy Press, Transportation Research Board Special Report 247, p. 36-75.

Weber, W.A., 1965, Plant geography of the southern Rocky Mountains, in Wright, H.E., Jr., and Frey, D.G., eds., The Quaternary of the United States: Princeton, N.J., Princeton University Press, p. 453-468.

Williams, P.L., and Cole, J.C., 2007, Geologic map of the Albuquerque $30^{\prime} \times 60^{\prime}$ quadrangle, north-central New Mexico: U.S. Geological Survey Scientific Investigations Map 2946, 31-p. pamphlet, 1 pl., scale 1:100,000 (also available at URL http://pubs.usgs.gov/sim/2007/2946/).

Woodburne, M.O., and Swisher, C.C., Jr., 1995, Land mammal high-resolution geochronology, intercontinental overland dispersals, sea level, and vicariance, in Berggren, W.A., Kent, D.V., Aubry, M.P., and Hardenbol, Jan, eds., Geochronology, time scales and global stratigraphic correlation: Society for Sedimentary Geology, Special Publication 54, p. 335-364.

Zielinski, R.A., 1982, The mobility of uranium and other elements during alteration of rhyolite ash to montmorilloniteA case study in the Troublesome Formation, Colorado, U.S.A.: Chemical Geology, v. 35, 185-204. 
Publishing support provided by:

Denver Publishing Service Center

Manuscript approved for publication June 9, 2010

For more information concerning this publication, contact

Center Director,

USGS Geology and Environmental Change Science Center

Box 25046, Mail Stop 980

Denver, CO 80225

(303) 236-5344

Or visit the Geology and Environmental Change Science Center

Web site at: http://esp.cr.usgs.gov 


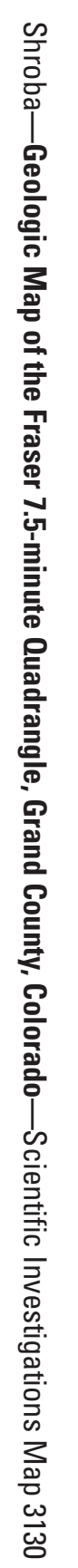

